Portland State University

PDXScholar

$11-24-1970$

\title{
Councils of Governments: a Study Focusing on Membership, Representation and Voting
}

Jerry Alan Matson

Portland State University

Follow this and additional works at: https://pdxscholar.library.pdx.edu/open_access_etds

Part of the American Politics Commons, and the Political Theory Commons Let us know how access to this document benefits you.

Recommended Citation

Matson, Jerry Alan, "Councils of Governments: a Study Focusing on Membership, Representation and Voting" (1970). Dissertations and Theses. Paper 1552.

https://doi.org/10.15760/etd.1551

This Thesis is brought to you for free and open access. It has been accepted for inclusion in Dissertations and Theses by an authorized administrator of PDXScholar. Please contact us if we can make this document more accessible: pdxscholar@pdx.edu. 
AN ABSTRACT OP THE THESIS OF derry Alan Matson for the Master of Arts in Folitical Science presented November 24,1970

Title: Councils of Goverments: A Study Fochising on Nembership, Representation and Voting.

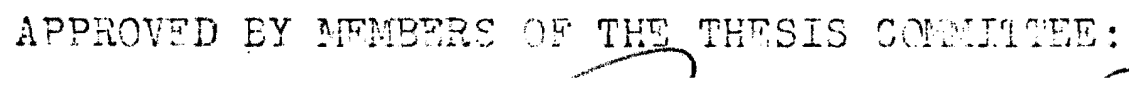

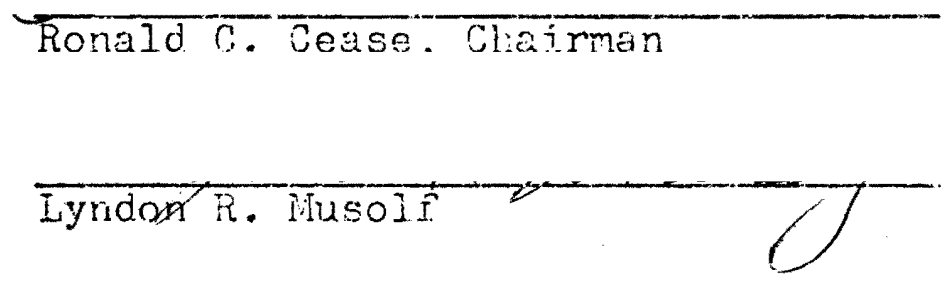

The Council of Governments is a sigrificant new approach to metropoitan cooperation. OI the approximately 150 douncils (as of January, 1970), al.1 but ilt have boen established since 1965. Councils across the country are characterized by great variety jn orsanization and representation. This paper examines this conplexity, particularly in terms of membership, representation and voting.

The first chapter is primarily a short history of the council moverent and the forces winth have helped to shape its deveioprent. The seconi examines the variegy of courcil punctions, ormanzational structures and Anancial arrangements. 
Chanters III, IV and $V$ are devoted to a detailed study of meribership, representation and voting patterns. While the third and fourth chapters are concerned with the general asfects of these patterns, Chapter $V$ examines in detail the arrangements usea by tweive specific councils. The effect of the "one man, one vote" concept on councils is discusseci in the sixth chapter.

The concluding chapter analyzes the external and internal problems facing councils and their success in meeting these problems. The future development of councils is also explored.

While the future of the councils and the novement may take one of many avenues, including evolution into regional governments, it appears that the likely development will be mixed. Uniformity will continue to be imposed by HUD regulations, but the local councils will continue to explore for experimental solutions to satisfy their own individual problems and neecs. 
COUNCILS OF GOVERNMTNTS: A STUDY FOCUSING ON MEMBERSHIP, REPRESENTATION AND VOTING

by

JERRY ALAN MATSON

A thesis submitted in partial fulfillment of the requirements for the degree of

MASTER OF ARTS

in

POLITICAL SCITNCE

Portland State University

1970 
TO THE OFYICE OF GRADUATE STUDIES:

- The members of the Committee approve the thesis of Jerry Alan Matson presented November $24,1970$.

Ronald C. Cease, Lhairman

Lyndok R. Musolf

APPROVED:

Norman N. Greene, Head, Department

ge Political, Science

David T. Clark, Dean of Graduate Studies

Novemuer 24, 1970 
TABLE OF CONTENTS

PAGE

CHAPTER

I INTRODUCTION.................. I

Early Developments.............. 4

Fncouragement by Professional Organizations

Advisory Commission Recommendations

Federal-Aid Highway Act of 1962

Recent Developments.............

Title II, Sections 204 and 205

National Service to Regional Councils

II FUNCTIONS, ORGANIZATION AND FINANCING...

Functions................. 15

Review Powers of Councils

Other Functions

Legislative Programs

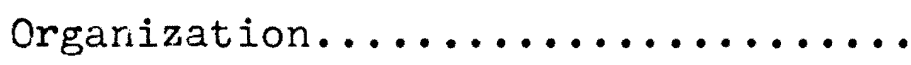

22

General Requirements

Council Policy-ilaking Bodies

Communication Problerns Within Councils

Council Officers

Committees and Staff

Financing.................

34

Membership Dues

Federal and State iid

Other Sources 
II COUNCIL MEMBERSHIP............... 40

State and Federal Requirements..... 40

HUD Requirements and Guidelines

Advisory Commission Recommendations

State Requirements

Council Restrictions............ 46

Types of Restricted Membership

Kinds of Hember Governments

Other Niembers

Size of Council Membership

IV REPRESENTATION AND VOTING..........

Representational Systems..........

Restrictions on Non-Elected

Nember Representatives

Elected Nember Representatives

Lay Representation on Councils

Geographic Versus Interest Group Representation

Voting Systems...............

"One Unit, One Vote"

"Weighted or Froportional Voting"

"One Man, One Vote"

The Appeal of Population-Based Systems

$V$ REPRESTNTATION AND VOTING: SELECTED SYS-

TEMS

Geographic Factors..............

Louisville, Kentucky, Metropolitan Area

St. Louis Metropolitan Area

New York Metronolitan irea

Portland lietropolitan Area

Population Factors.............

Cleveland Metropolitan Area

Puget Sound Regional Area 
Pittsburgh Wetropolitan Area

Dallas-Fort Worth Mietropolitan Area

Washington Metropolitan Area

San Francisco Bay Regional Area

Other Arrangements.............

Boston Metropolitan Area

Chicago Kietropolitan Area

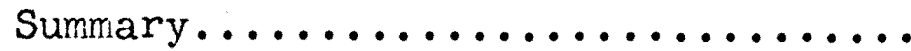

VI REPRESENTATION AND VOTING: ONE MAN-ONE

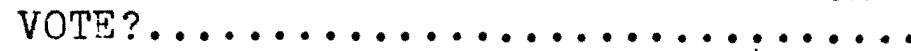

84

"Equal Representation"...........

84

The Avery Decision

The Hadley Decision

"Nothing to Prevent Experimentation.

86

The Sailors Decision

Reassertion in the Hadey Decision

Application of Equal Representation to Councils

VII CONCLUSION

Development

Externai Factors and Influences

Council Problems

Council Successes

One-Man-One-Vote

What Is the Future of Councils of Governments?

SOURCFS CONSULTED.....................

APPENDIX A............................ 121

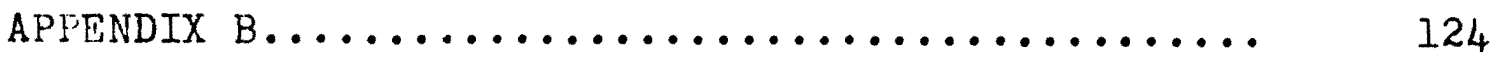




\section{CHAPTER I}

\section{INTRODUCTION}

The problems of a dynamic urban society are becoming increasingly complex. In the process of attempting to alleviate these problems, an equally complex arrangement of general and special purpose governmental entities has been created. As of 1967, the thirty seven largest metropolitan areas of this country had over 9,340 local governments.I

Many attempts have been made to improve this situation. Since 1921, when the first state legislation permitting intergovernmental agreements was enacted, local governments have attempted to alleviate the problems. 2 A majority of these efforts have been aimed at increasing intergovernmental coordination through the use of joint service contracts and other special purpose agreements. However, the first efforts to provide for the coordination of local planning activities did not take place unti] after World War. II with the establishment of

IU.S., Advisory Commission on Intergovernmental Relations (ÁCIR), Fiscal Balance in the American Federal System, Vol. II: Metropolitan Fiscal Disparities, Report No. A-31 (Washington: October, 1967), p. 102 .

2U.S., ACIR, A Hancibook for Interlocal Agreements and Contracts, Report No. M-29 (Washington: March, 1967). 
inter-local planning bodies. These early bodies included the Central Lane Planning Council, formed in 1945 in Eugene, Oregon; ${ }^{3}$ the Detroit Metropolitan Area Regional Planning Commission, formed in $1947 ;^{4}$ and the National Capital Regional Planning Council of Washington, D.C., formed in 1952.5

Despite these initial developments, cooperation and planning on a metropolitan basis became a matter of high priority only when government "was complicated by the growth of local functions and burdened with serious physical, social and economic problems." 6 The first significant national program to encourage the development of metropolitan planning was not enacted until 1954. This program, encompassed in the Section 701 provisions of the Housing Act of 1954, provided planning grants to

official state, metropolitan, and regional planning agencies empowered under state or local law or interstate compact to perform metropolitan or regional planning.7

${ }^{3}$ Central Lane Planning Council, A Creative Aprroach to District Planning, (Eugene, Oregon: January, 1970).

4 Committee of One Hunöred, A Proposal for a Voluntary Council of Governments in Southeast Michigan, (Detroit: June, 1966), p. 29.

5 Roscoe C. Martin, Metropolis in Iransition, (Washington: 19631 , p. 41 .

${ }^{6}$ Douglas Harman, "Councils of Governments and Metropolitan Decision-Making," The Municipal Yearbook 1969, (Washington: 1969), p. 11.

7U.S., Housing Act of 1954 , 68 Stat. 590, as amended by the Housing Acts of 19.56, 1957 and 1959, 70 Stat. 1091, 
A new form of intergovernmental arrangement was also created in 1954. This was the council of governments. 8 While councils of governments are not a new level or form of regional government, they are important regional associations of governments. Acting primarily as voluntary organizations, the councils have no direct control over the affairs of their members, and most members have freedom to withdraw. 9

The councils may be established by use of several methods: specific state enabling acts, general excercise of joint powers statutes, intergovernmental agreements, corporate charters, or simple extralegal arrangements.10 By whatever means used, a council's success rests principally on the local environment, incluaing the good will evinced by its members.

Since membership in councils is normally initiated and 71 Stat. 294, and 73 Stat. 654, Section 701 (a).

8See Appendix A for a definition of councils of governments and for an indication of how these bodies differ from other forms of regional governmental entities.

9Members of councils established by specific state enabling acts are in some cases not permitted to withdraw without specific legislative action. However, there is no legal bar to withdrawal in most cases. Of course, practical and political factors would generally preciude such actions as a meaningful option.

10Royce Hanson, Metropolitan Councils of Governments, ACIR Report No. M-32 (Washington: August, 1966), p. I. 
by voluntary local actions,ll

it must be generated at the local level. It must be controlled by local elected officials. Resultant action or implementation of functions must be locally by the member governments rather than the council itself. 12

However, as a forum for the discussion of metropolitan issues, the councils provide excellent formal tools for the coordination and cooperation of local governments.

\section{EARLY DEVELOPMENTS}

The first recosnized councils of governments was the former Supervisors Inter-County Committee, formed in 1954 , by the leaders of the six counties in the Detroit metropolitan area. At that time there was no state law on such bodies. The membership did not seek legal sanction until three years later; the council was then successful in getting the state to adopt appropriate legislation.13

The second council, however, was not established until 1956. Mayor Wagner of New York City, following the

${ }^{1}$ Increasingly, a number of states are assuming a leading role in the foundation of councils. In fact, in Oregon the state government is encouraging the formation of new councils with a missionary zeal.

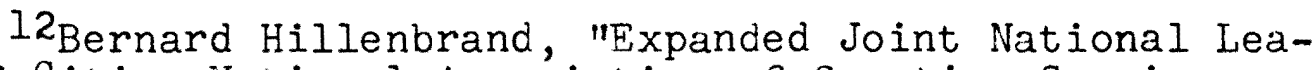
gue of Cities-National Association of Counties Service Programs for Regional Councils," prepared for the National Association of Counties and the National League of Cities, proceedings of the Workshop on Voluntary City-County Regional Cooperation, (New Orleans: July 19, 1966), p. 22 .

13 Conmittee of One Hundred, op. cit., p. 23. 
earlier Detroit example, invited neighboring local officials in the New York metropolitan area to join with him in forming the Metropolitan Regional Council. This council was initially established as a non-profit corporation in October of 1956.14

Shortly after the creation of the New York council, local officials in the Seattle area formed the Puget Sound Governmental Conference (1957). In the same year Robert E. Mclaughlin, president of the District Board of Commissioners in Washington, D.C., invited representatives of the governing bocies of the suburban jurisdictions and the legislatures of hiaryland and Virginia to discuss the possibility of creating a new areawide agency. After several meetings an organization called the Washington lietropolitan Regional Conference evolved in November, 1957.15

In late 1958, the informal Mid-Willamette Valley Intergovernmental Cooperation Comittee was organized, and in December, 1959, the members entered into a formal compact. 16

Attempts by the State of California (beginning in

14 Harman, op. cit., p. 11 .

15Martin, on. cit., p. 43. The name of the vashington conference was changec in 1962 to the Wetropolitan Washington Council of Governments.

${ }^{16}$ Ibid., p. 31. The name of the comriltee was later changed to the Mid-ililamette Valley Council of Governments in 1962 . 
1959) to reorganize governmental services in the San Francisco Bay region eventually led to the formation of the Association of Bay Area Governments. These efforts originally centered on the creation of a regional planning commission, the "Golden Gate Authority." While this attempt was narrowly defeated in the legislature in early 1961, the controversy stimulated interest in creating an organization of local governmental officials to influence legislation affecting the region and to coorainate local programs and policies. Early in January, 1961, these local officials established the Association of Bay Area Governments. 17

Later in 1961 two other councils of governments were formed; the Regional Conference of Elected Officials in the Philadelphia region, and the Metropolitan Des Moines Area Council. 18

\section{Encouragement bv Professional Organizations}

Attempting to encourage further development of regional cooperation, the American Municipal Association held its 1961 annual congress in seattle on the theme of "Intergovernmental Cooperation." The major highlight of this conference was a workshop session to which invitations

17 Stanley Scott and John C. Bollens, Governing a Metropolitan Region, (Berkeley: 196e), pp. 11-12.

$18^{T}$ The Des Moines council was soon disbanded. 
were extended to officials

of all regional councils which had been formally established for the express purpose of multi-purpose regional or metrorolitar coordination of governmental activities.19

The congress ended with the passage of a resolution to continue the association's interest in

exploring cooperation with the National Association of County Officials and other appropriate national organizations in encouraging voluntary multi-purpose regional organizations. 20

The First Joint American Municipal Association National Association of County Officials Voluntary Regional Organization Workshop Neeting was held in New York on May 25, 1962. The delegates resolved to recommend to their respective associations a seven-point program to provide joint services to existing regional organizations and to provide help and encouragement to local officials interested in establishing new councils. 21

\section{Advisory Commission Recommenations}

In 1961 the Advisory Commission on Intergovernmental Relations began a series of reports with strong recommendations to local state and national governments to help

19 Kent Mathewson, Workshop on Voluntary MultiPurpose Regional Organizations,' prepared for the American lunicipal Association, (Washington: 1961), p. 1 . ${ }^{20}$ Ibid., p. 9.

$2{ }^{2}$ National Association of Counties and the American Municipal Association, Voluntary City-County Regional Cooneration, (Nashington: 1963), p. 9 . 
to encourage and facilitate areawide planing. The report on governmental structure end organization, published in july, 196], was the first to suggest alternative methods for areawide planning, inclucing the developrient of councils of goverments. The report suggested that states authorize the creation of metropolitan planning bodies, financially and technically assisted by the states, to help in controlling metropolitan problems. Other reconmendations concerned the improvement and expansion of federal financial and technical assistance to state and metropolitan planning agencies.22 Finally, the Advisory Commission recommended that all applications for certain federal grantsin-aid programs

located within metropolitan areas ... bear evidence of having been reviewed and commented upon-not necessarily approved-by a legally constituted metropolitan planning agency having scope anci responsibility for comprehensive planning for the metropolitan area and being representative of the population and governmental units as a whole.23

In June, 1962, the Advisory Commission issued a follow-up report elaborating several suggested methods of metropolitan reorganization and coordination. The report reviewed in depth the advantages and disadvantages of these metrods. Incluaed in the report was a discussion of the metrorolitan councils of goverments. 24

22U.S., ACIR, Governmental Structure, Organization, and Planning in Metropolitan hreas, Report No. $A-5$ (ifashington: July, 1901), chapters IV and V.

$$
23 \text { Ibic., p. } 49 .
$$


Federal-Aid Hismoy Aet of 1902

Several of the Advisory Commission's recomnendations were incorrorated into the Federal-hid Highway Act of 1962.25 Under the provisions of the Act, urban areas of over 50,000 population were required to base all feceralaid highway projects uron a continuins, conprehensive transportation planning process, carried on cooreratively by staties and local cormunities. Regional councils were allowed to perform the work and could be given full or partial responsibility by the local states for implementing the planning process. 26

\section{RECENT DTVELOPRENTS}

The first major legislation designed specifically to encourage the development of regional councils was the Housing and Developrient Act of 1965. The most important provision in the legislation, Section $701(\mathrm{~g})$, was a stipulation that additional grants, other than planning would be given

to organizations composed of public officials whom he $\sqrt{a}$ Federal Ajministrator 7 finds to be representative of the political jurisoictions within a

24U.S., ACIR, Alternative Annroaches to Governmental Reorganizat on in Metropolitan Areas, Report No. A-II (Washington: Juno, 1902), pp. 34-38. 1145 .

25u.3., Federal-Aid Highwav Act of 1962, 76 stat.

$26_{\text {National Service to Regional Councils, Key Federal }}$ Programs, Special ieport No. 7, July, 1.908 , pp. 5-0. 
metropolitan area or urban region for the purpose of assisting such organization to undertake studies, collect data, develop regional plans and programs, and engage in such other activities as the Administrator finds necessary or desirable for the solution of the metropolitan or regional problems in such areas or regions.... A grant under this subsection shall not exceed two-thirds of the estimated cost of the work for which the grant is made.27

Encouraged by this provision, many local governments began to explore the possibility of gaining additional grants by establishing regional councils, especially councils of governments. 28

By 1964 , ten years after the establishment of the Detroit area council, only nine councils of governments were in operation. 29 Many other attempts were made to establish councils, but they failed due to a variety of local problems. With the passage of the Housing and

27 Hanson, op. cit., p. 59.

${ }^{28}$ Inspired by the renewed interest in councils of governments, the Advisory Commission on Intergovernmental Relations decided to undertake an additional study of the council concept. Essentially, the purpose of the study was "to describe the councils of governments, how they can be developed, what they do and how they can become more effective through the use of the new Fiederal assistance program." Ibid., p. iii.

29They were the Supervisors Inter-lounty Committee (Detroit), the iletropolitan Regional Council (New $Y_{O} r k$ ), the Puset Sound Governmental Conference (Seattle), the Metropolitan Washington Council of Governments, the MidWillamette $V_{a} l$ ley Council of vovernments, the Association of Bay trea Governments, the Regional Conference of Elected Officials (Philadelphia), the Southern California Association of Governments (Los Angeles), and the lletropolitan Atlanta Council of Local Governments. Scott and Bollens, on. cit., pp. 87-88. 
Development Act of 1965, however, a sharp revival of interest in councils developed. By the end of 1965 there were at least fourteen new councils of governments in various stages of growth. 30

\section{Title II, Section 204 and 205}

While the federal government's encouragement had helped the development of councils, the Housing and Development Act of 1965 set no initial criteria for their establishment and development. However, the next year Congress passed the Demonstration Cities and Metropolitan Development Act of 1966. Title II, Section 204, of the Act, adopting an earlier Advisory Commission recommendation, requires the local review of metropolitan area grants. After June 30, 1967, all applications for federal loans or grants for certain metropolitan area projects must be submitted for review

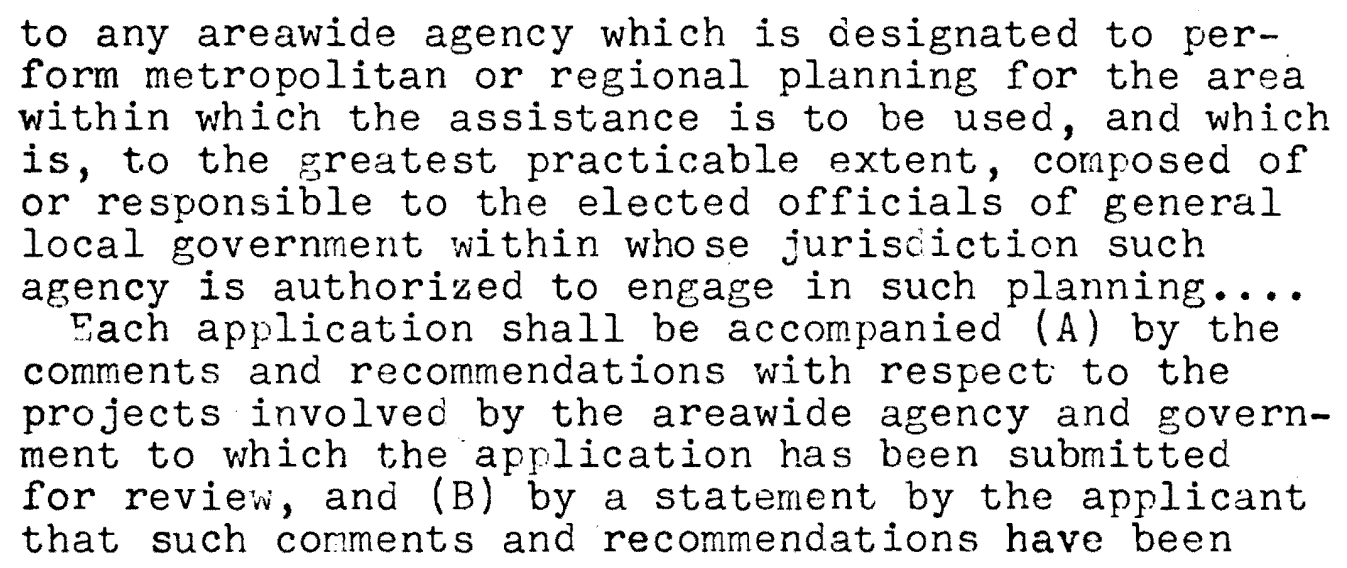
form metropolitan or regional planning for the area within which the assistance is to be used, and which is, to the greatest practicable extent, composed of or responsible to the elected officials of general local government within who se jurisciction such agency is authorized to engage in such planning.... Each application shall be accompanied (A) by the comments and recommendations with respect to the projects involved by the areawide agency and government to which the application has been submitted for review, and (B) by a statement by the applicant that such comments and recommendations have been

30Harman, op. cit., p. 11. 
considered prior to formal submission of the application. 31

Furthermore, supplemental grants for metropolitan development projects may be provided when three significant conditions expressed in Section 205 of the Act are followed. These conditions are: (1) the area in question has adequate areawide comprehensive planning and programming; (2) there is adequate areawide institution or other arrangements for coordination; and (3) projects which have a major impact on the area are in fact being carried out in accord with the areawide planning and programming. 32

All regional planning organizations, especially councils of governments, were given significant additional responsibility for the coordination of a wide variety of federal grant programs. Immediately, there was a rapid development of new councils, as well as other regional planning organizations. By February, 1969, an estimated 142 councils of governments were in various stages of development and operation. 33

31U.S., Demonstration Cities and Metropolitan Development Act of 1966 , 80 Stat. 1262 , as amended by the Housing and Urban Development Act of 1968, 82 Stat. 448 .

32 Ibid.

33Harman, op. cit., p. 10. See Appendix B for a partial listing of councils of Governments. 
National Service to Regional Councils

Aiding this development and expansion of regional cooperation, the American Municipal Association and the National Association of County Officials continued to provide materials and workshops to local officials interested in establishing regional councils. 34 Eventually, this task grew so large that the two associations co-sponsored in 1967 the formation of the National Service to Regional Councils.

The National Service performs a number of activities aimed at encouraging the creation of regional councils, and is fostering their cevelopment and operation. The National Service publishes a newsletter informing members of significant developments in the field of regional politics. In addition, the organization has published a number of reports and studies examining all aspects of regional cooperation. A principle task of the National Service is to "watch over national legislation and executive actions which affect councils of governments." 35

Recently there has been some discussion among council officials concerning the separation of the National

34 The names of these organizations were changed to the National League of Cities and the National Association of Counties, in 1966, and 1963, respectively.

35 Harman, on. cit., p. 11. 
Service from its parent organizations. While the National Service is separate and an indepencient corporation, it still receives most of its funding, staff aid, and research facilities from the parent organizations. At present the discussion to end this arrangement coes not appear to have much surport. 36

36Interview with Karl Van Asselt, Assistant Director, League of Oregon Cities, Salem, Oregon, September 23,1970 . 
FUNCTIONS, ORGANIZATION AND FINANCING

Throughout the country councils of governments appear to have developed many common patterns of functions, organization and financing. These patterns result from the many common problems facing councils everywhere. Furthermore, the many feceral requirements also insure great standardization of council powers and procedures. However, diversity is also imposed by pervasive state and local conditions and interests.

\section{FUNCTIONS}

Voluntary regional councils, such as councils of governments, 1 are attempting to create the necessary compromise between the desire to retain local control and the necessity for areawide coordination. These councils are working to ameliorate the interlocal suspicions and hostilities, and are attempting to develop constructive and workable programs and policies based upon the needs of their particular regions.

A majority of the councils have accepted the

${ }^{I}$ See Appendix A for a discussion of the different forms of regional councils. 
necessity to base their programs and policies upon a general consensus. Many local council officials believe that

the Council ought to play an advisory role and if local units don't want to accept the advice, that is up to them $\Gamma_{\text {sic }} 7$.... The Council and its members should concentrate on and exploit the areas of agreement and should not be overly concerned with the divisive aspects.2

\section{Review Powers of Councils}

Using the general consensus corcept as a base, a majority of councils throughout the country have developed many common functions and poners. However, the most important functions performed by councils of governments are the review functions given to them by the feceral government under the provisions of the Demonstration Cities and Metropolitan Development Act of 1966 . This review power with its inherent coercive aspects has helped to encourage further regional cooperation among council members.

Approximately 85 councils of governments are currently designated as review agencies by HUD. ${ }^{3}$ These councils review all applications for certain federal loan and grant programs in their areas:

2Mid-Cumberland Council of Governments, A Proposed Role for the Mid-Cumberland Council of Governments, prepared by David Grubbs, (Nashville: November, 1968), p. 11.

${ }^{3}$ National Service to Regional Councils, Regional Council Profiles, (Washington: Narch, 1969). 
(1) to assist in carrying out open-space land projects; or

(2) for planning on construction of (a) hospitals and selected health facilities, (b) airports, (c) libraries, (d) water supply and distribution facilities, (e) sewage facilities and waste treatment works, (f) highways, (g) transportation facilities, and (h) water development, and land conservation projects. 4

Once the application has been submitted to the responsible council, the proposed project is tested to determine whether it is consistent with the goals which have been adopted by the council. The council also ascertains whether the project meets regional standards and is in conformance with the areawide planning for the region. If the council endorses the project as proposed, it recommends to the appropriate federal agency that the application be approved. If the council cioes not endorse the project, it recommends that certain specified changes be made before approval, or states the reasons for the rejection. In those areas where councils have not yet established regional priorities, the bodies tend to rubber stamp most requests submitted to them. But when councils do return proposals to the local governments for reconsideration or alterations, the latter appear to comply with the council recommendations. In any case, the council's role is purely advisory and does not carry with it the power of final approval or rejection. Final

40hio-Kentucky-Indiana Regional Planning Authority,

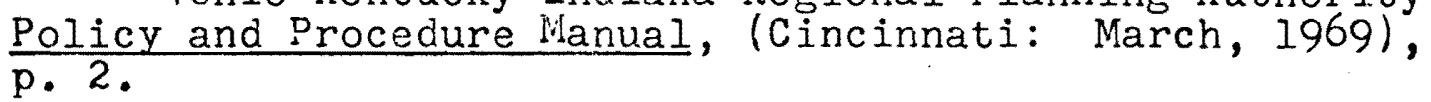


authority rests solely with the federal agency to which the request is made. 5

The review functions given to the councils by the federal government are important. A majority of councils were created in direct response to the Section 204 provisions of federal law. Local goverrments in several metropolitan areas have been refused federal funding until the governments in the area concerned combined to establish a review agency approved by the Department of Housing and Urban Development.

In the Portland metropolitan area, for example, federal aid for several important projects was denied until the local governments created the Columbia Region Association of Governments and it was approved by HUD. Sewer grants to Multnomah County (more than $\$ 1.1$ million), as well as grants for planning studies and public works projects to other local governments, were denied until HUD was satisfied that there was an appropriate regional body. The funds were provided when the condition was met. 6

5Ibid., pp.3-5, and a letter from Stanley Scott, Assistant Director, Institute of Governmental Studies, University of California, Berkeley, California, September 17, 1970.

6Letter from Robert Pitts, Regional Administrator, Region VI, HUD, to McKay Rich, Executive Director, Portland Metropolitan Study Commission, August 10, 1966, and "Sewer Work Delayed as Grants Held Back," Oregonian, June 24, 1966, p. 20, and "Delay in Planning Held Expensive to County," Oregonian, September 22, 1966, p. 35. 
While the review process has been instrumental in the expansion of councils, many councils perform no review functions. Approximately 26 councils are currently not certified as review agencies by HUD because they do not meet a number of specific federal requirements. For example, in the cases of the Council of Governments of Cook County, Illinois, and the Regional Conference of Elected Officials (now the renjerdel Council of Governments) of the Philadelphia area, there are other recognized review agencies serving the same regional areas. 7 In other areas some councils do not contain the entire metropolitan area, do not meet other specific legal requirements, or do not perform all the necessary functions of a review agency.

\section{Other Functions}

All councils also perform functions other than review. In fact, a National Service to Regional Councils' survey concucted in late 1968 disclosed that a majority of council officials believe that the council's basic role is not review but one of education and the distribution of accurate metropolitan information. Typical responses to the survey stated that councils are

7Letters from Phil A. Doyle, Director, Council of Governments of Cook County, Illinois, February 6, 1970, and from Jack R. Nelson, Acting Executive Director, Penjerdel Council of Governments, Philadelphia, Pennsylvania, January $19,1970$. 
"providing communication and developing awareness and discussion of problems" and are promoting the "spirit of cooperation. 8

Councils perform a variety of functions concerning regional problems. They operate

to serve as a mutual forum to identify, discuss, study and bring into focus regional challenges and opportunities.

to serve as a vehicle for the collection and exchange of information of regional interest.

to provide a continuing organizational machinery to insure effective communication and coordination among governments and agencies.

to foster, develop, and review policies, plans, and priorities for regional growth, development, and conservation.

to facilitate agreements and cooperative action proposals among member governments for specific projects or other interrelatea developmental needs and for the adoption of common policies and plans with respect to common regional challenges.

to maintain liaison with members, governmental. units, and groups or organizations and to serve as regional spokesman for local government.

to furnish general and technical aid to member governments, as they direct, to promote and accomplish $9^{\text {council approved agreements, policies, and }}$

\section{Legislative Programs}

While a majority of councils have chosen not to develop or promote legislative programs, several of the older ones have launched themselves deeply into this area. pp. 5-6.

OMid-Cumberland Council of Governments, op. cit.,

9National Service to Regional Councils, Regional Council By-Laws, Special Report No. 3, May, ig68, p. 6. 
The Association of Bay Area Governments, for instance, has been urging the California Legislature since 1966 to reconstitute the association as a "formal regional government with limited functions, but with the intention of eventually taking over Bay conservation and development."10

Other councils have been selected by state and federal governments to develop legislation. The Alamo Area Council of Governments of San Antonio, Texas, for example, was selected by the state to develop prototype health planning, law enforcement and acministration of justice, and water quality programs, which were submitted as legislation. 11

In general, however, the majority of councils avoid recommendation of any specific legislation. The following statement made by an official of the Mici-Cumberland

10In 1969 ABAG proposed that it assume the responsibilities of the Bay Area Conservation and Development Commission, a body with basic responsibility for protecting the San Francisco Bay shoreline. However, the California Legislature chose instead to continue the Commission indefinitely. This is a good example of the State's refusal to accede to ABAG's requests to reconstitute it as a formal regional government. Moreover, in 1970, the Legislature chose to create a separate regional transportation entity instead of investing the functions in ABAG. Scott and Bollens, op. cit., p. 148, and Ora Huth, Regional Organization in the San Francisco Bay Area--1970, (Berkeley: Institute of Governmental Studies, April 18, 1970); pp. 2, 7 and 14.

IIAlamo Area Council of Governments, Program 1970 , (San Antonio: December, 1969), pp. 1-3. 
Council of Governments, (Nashville, Tennessee) indicates the view commonly held by council officials:

It was generally felt that the Council as an entity ought not to develop a legislative program.... The same feeling applied to the matter of getting legislation adopted. It was felt that mayors and county juciges could operate through their respective organizations in this regard and not involve the Council as such.12

\section{ORGANIZATION}

A majority of the important councils have developed complex organizations as a result of strong internal pressures. While a majority of councils have basic similarities and follow common patterns, many councils have found it necessary to develop unusual arrangements, often as a result of these pressures and the difference in state laws. However, all councils acting as review agencies have many similarities imposed by federal requirements.

\section{General Requirements}

All metropolitan councils of governments, which have been designated review agencies, must be legally constituted bodies

authorized by state law or interstate compact to perform comprehensive planning; and programming. Local governments must join by official action. p. 32 .

12Mid-Cumberland Council of Governments, op. cit., 
Public agencies are preferred to non-profit corporations.13

Furthermore, these bodies must

have authority to receive and expend Fecieral and other funds; have the authority to contract with the Federal government and, as appropriate, contract with other units of government, private concerns, or individuals for the performance of planing work and services; and be able to assure HUD that the non-Federal share of the planning grant will be provided.14

In addition to federal requirements, many states regulate the establishment and conduct of metropolitan governmental agencies and non-profit public corporations. Furthermore, council organization and structure are often affected by the inherent dissimilarities between metropolitan regions. Responding to their many local problems, councils have resorted to experimentation in creating their organizational arrangements. However, all councjls can generally be structually separated into their administrative legislative functions. 15

13The only exception to this requirement arises when a region extends into more than one state. If a state's "enabling legislation does not permit an official multistate agency, an unofficial Coordinating Committee for the entire Metropolitan Region may be formed." U.S., Department of Housing and Urban Development (HUD), Comprehensive Flanning Assistance, (Washington: March, 1969i,p.40.

14 Ibid., p. 41 .

15For purposes of this study, council "administration" includes staff and technical-advisory bodies. Obviously, these elements influence policy and often make it. 
Council Policy-Making Bodies

The major difference between councils is their decision-making systems. Councils vary widely in the authority, complexity, size and number of policy-making bodies they contain. Council structures range from the simple one level organization to the more complex two- and threetiered ones.

There are many reasons for the development of these different forms. They range from attempts to eliminate coordination problems within the council to offsetting the influence of the multitude of smaller council members. The smaller councils, not having the same kinds of problems, generally use the simpler council structures. Single-Bodied Councils. As a general rule, the small councils with fewer than fifteen representatives on their policy-making body use this simple organization. The regular meetings of these councils are held often, usually monthly. Moreover, special meetings are quite common. All meetings are normally informal and flexible. The problems of council authority and leadership are generally solved quickly as a result of mutual respect and a desire to complete the tasks confronted or are avoided in order to prevent open conflict. 16

16 Several of the smaller councils have bitter power struggles which have seriously hampered their work. 
Two-Tiered Councils. The majority of council, however, have found it necessary to develop a more complex form of organization by adding a smaller, more intimate body. This smaller body is usually called the executive committee or board. The executive committee is often used to expedite the day-to-day business of the council. The majority of executive committees, however, appear to have been formed to offset the influence of the many smaller council members. Currently, the majority of executive committees have a preponderence of representatives from the larger jurisdictions.

In a few cases the executive committees are attempts to overcome the problems of member apathy. Some councils find it difficult to obtain a quorum for their meetings unless there is a small executive committee of interested members to conduct council affairs. For example, according to the director of the Baton Rouge council,

our Executive Committee, as you will note (in the council by-laws), was created merely for the purposes of providing an assurance that a quorum for the conduct of business can be attained at regular monthly meetings. 17

For whatever reasons the executive committees may be established, they face many important and pressing

17Letter from Sidney Gray, Executive Director, Capital Region Planning Commission, Baton Rouge, Louisiana, December 29, 1969. 
problems:

The most important problem for the executive committees is to bring together the local officials who are willing and able to provide leadership for the organization. If a rotation system is used, for instance, in selecting the executive committee representatives, then the quality, power, and leadership of the executive committee varies with chance rather than choice.18

The general assemblies of the two-tiered councils usually meet semi-annually or arnually. When the meetings are held, the general assemblies usually have a chance to endorse only the policies developed by their executive committees concerning the council's general work programs and policies. The executive cormittees, in effect constitute the focus of the council's leadership and direction and are the most important decisionmaking bodies of the councils.

These (executive) committees supervise the staff, maintain liaison with other regional groups, prepare policy recommendations for the general membership, make the budgetary decisions and otherwise act in behalf of the entire organization. The executive committees also assign projects to the standing or ad hoc committees and review the work of these committees. Technically, the work of the executive committees is subject to review by the full membership, but as a matter of practical politics, executive committee actions are rarely, if ever, reversed. Both overlapping mernbership and caution contribute to this result.19

There are a few major variations from the standard two-tiered councils. One unique and interesting example

18Hanson, op. cit., p. 18.

19I Ibid. 
is found in the Miami Valley Council of Governments of Dayton, Ohio. This council may even be called a quasithree-tiered council. The council has the normal general assembly and "general executive committee," with typical authority, but also an "educational executive committee." The educational executive committee, consisting of all educational members of the council, controls all council affairs concerning education. This committee operates in conjunction with, but not subordinate to, the general executive committee. 20

Three-Tiered Councils. The most complex council organizations are the three-tiered structures. There are currently at least three councils using this basic form. The first council to cevelop this structure was the former Regional Conference of Elected Officials of Philadelphia. The reason for its development was to provide a workable organization for the large number of council members. In addition, provisions were made in the bylaws to ensure that the larger council members would have greater voting strength in the council than the multitude of smaller members.

Under this original three-tiered approach, the largest council body was called the Conference and was composed of all council members. It held annual meetings. However, the Conference had no real authority

2 MIiami Valley Council of Governments, Sample Bylaws, (Dayton, Ohio: December, 1967), Articles IV and V. 
and could only act as a general forum for the discussion of mutual problems, make recommendations to the other two more important council bodies, and elect the officers of the organization. 21

The body immediately superior to the Conference was called the "Council." The Council was smaller but more important. It was composed of the larger jurisdictional members and a few representatives from the smaller jurisdictions. The power of the Council included the making of all final decisions. Its meetings were held semiannually.

The smallest and most important body was the Executive Committee. This body contained only the largest cities and counties and nominal representatives from the smaller members of each state. The powers of the Executive Conmittee included the making of all organizational decisions between regular meetings of the Council. It was responsible also for the general administration of the staff. The Executive Committee was scheduled to hold its regular meetings at least five times a year. 22

However, in October, 1969, the Regional Conference

$21_{\text {National Association of Counties and the American }}$ Municipal Association, op. cit., "By-laws: Regional Conference of Elected of ficials."

22 Ibid. 
of Elected Officials underwent a major reorganization with a change in structure and name. It became the Penjerdel Council of Governments:

I am very happy to report that we no longer have the three-tiered structure.... We now have the Council (of governments) and the Board of Directors. Essentially, the old Council and Conference have been absorbed by the (new) council. This streamlining helps to facilitate the aciministration of this organization.

In fact, the old Council never worked and met only a few times in the last six years...23

While this basic structure obviously has many inherent problems, the Allegheny Council for Intergoverrmental Action of the Pittsburgh area still uses the pattern cieveloped in Philadelphia. The only major difference is that the Allegheny Council is solely an intra-state organization. 24

Another important council using the three-tiered approach is the North Central Texas Council of Governments of the Dallas-Forth Worth metropolitan region. Because of the narrow interpretation of state law, this council found it necessary to create a third organization within the council's structure but which is legally independent of it.25 Essentially, the General

23 Letter from Jack Nelson, Acting Executive Director, Penjerdel Council of Governments, Philadelphia, Pennsylvania, January 19, 1970.

$24 \mathrm{Allegheny}$ Council for Intergovernmental Action, Bylaws, (mimeographed, November 25, 1909), Articles IV-VI. 25 Philip W. Barnes, "Coping With Metropolitan 
Assembly of the council: has responsibility for approving the general policies and programs and for adopting the annual budget. The independent Regional Planning Commission operates as a major policy-making body of the council and has a membership identical to the council's. This commission shares staff, officers and finances with the council. The Executive Committee of the council and the commission are the same. The executive body provides the leadership and makes the major policy decisions. It is responsible to both the council and the commission for the administration of general policies and programs and for budget proposals. 26

The Metropolitan Washington Council of Governments, on the other hand, uses a structure essentially the same as the less complex two-tiered councils. However, the Board of Directors has a major Steering Committee, which is the actual third tier. The Steering Comnittee performs a major portion of the Board's business. It is controlled by the larger jurisdictions and is

composed of (1) the members of the Board representing all the participating governments with a population of 100,000 or more $\ldots$ and (2) an at-large.

Problems," Public Affairs Comment, XIII (Nay, 1967), p. 3. 26 North Central Texas Council of Governments, $\frac{\text { By-laws (Revised) }}{\text { and V. }}$ (mimeographed, n.d.), Sections II, IV 
Board member chosen from, and by, the participating governments having a population under 100,000.... The Steering Committee shall be responsible for preparing the business of the regular and special meetings of the Board of Directors, including the preparation of the annual budget. 2 ,

\section{Communication Problems Within Councils}

As councils increase in size and complexity, there develops a corresponding increase in prob]ems. One of the most important of these is the difficulty of internal communications. With the increase in the number of council bodies, there is a decrease in the percentage of local leaders who are involved with the important council decisions. The result is that only a limited number of local officials are

involved in meaningful discussion of regional issues. Some "members" of the voluntary association, as a result, may be unaware that they are members of it 38 since it requires so little of their attention. 28

As a result of this serious communications gap within the council's organization, many important decisions are made, and a decisive influence is exerted, by a relatively small number of officials. This power is centered in the executive committees, council officers, individual technical-advisory committees, and the council staff.

27Metropolitan Washington Council of Governments, By-laws, (mimeographed, Decernber 14, 1967), Section V. 28 Hanson, op. cit., p. 6 . 
Fach of these power centers can and does exert a major influence over council decisions.

\section{Council officers}

The officers are a vital element in the operation of the council. As a general rule, there are three officers: the chairman, vice chairman, and the secretary-treasurer. Several councils also have additional vice chairmen and separate the secretary and treasurer positions. The officers are usually elected at the annual meeting of the council's full general assembly. In many instances, the choice of candidates is limited by a nominating committee or by the executive committee, which may propose a list of favored candidates.

The chairman of the council presides over all meetings of the general assembly and the executive committee. Several councils also provide a different slate of officers to head the executive committee. The chairman usually determines the composition of each of the technical-advisory committees, controls the administrative staff, and determines the council's agenda during meetings.

\section{Committees and Staff}

The technical-advisory committees investigate and recommend courses of action for issues before the council. Where representation on the council is restricted to elected officials only, sub-committees are often staffed 
with professional administrators and other interested individuals. The committee structure on all councils is generally quite flexible and is constantly changing. The staff, on the other hand, is a permanent fixture of the council. It is headed by an executive director. The staff performs the administrative functions of the councils and conducts many of the detailed studies. A large number of smaller councils do not have full-time staffs of their own and must borrow personnel from their membership. Civic organizations, universities and private foundations sometimes provide staff assistance.29

In the opinion of one authority,

the speed with which a council develops and the range of activities it undertakes is largely a function of staff capacities and interest. No other single element seems as important in the development of councils. The trials and length of the formative period can be substantially reduced with able staff. The relative progress of the existing associations can almost be measured by the degree of staff competence and initiative. 30

29There are many different types of organizations which provide staff help to councils of governments: (1) the Maricopa Association of Governments (Phoenix) is staffed by the League of Arizona Cities and Towns; (2) the San Diego County Comprehensive Planning Organization is staffed by the county's Chief Administrative Office; (3) the Council of Governments of Cook County, Illinois is staffed by the Center for Research in Urban Government of Loyola University; and (4) the Allegheny Council for Intergovernmental Action is staffed by the University of Pittsburgh and the Pennsylvania Economy League (Western Division).

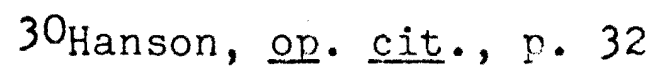


The size of the council staffs varies from no fulltime personnel to approximately 75-80 persons currently employed by the Metropolitan Washington Council of Governments. The vast majority of councils have less than 10 employees. 31

A few of the larger councils have indiviouals and sections specializing in planning, engineering, data processing, law, drafting, cartography, economics, and research. Probably the most sophisticated organization is the Washington council which is divided into eight departments: community resources, public safety, public affairs, administration, data systems, health and environmental protection, regional planning and transportation planning. 32

\section{FINANCING}

A major problem hincering the development of a majority of councils of governments is the lack of adequate and reliable financing. The small number, size and consistency of financial resources available to councils has prevented many of them from obtaining sufficient

31National Service to Regional Councils, Regional Council Profiles, op. cit.

32Letter from Walter $\mathrm{E}$. Scheiber, Executive Director, Metropolitan Washington Council of Governments, Washington, D. C., December 29, 1969. 
and capable staffs. In several instances, these problems have prevented the councils from obtaining any full-time staff personnel. In addition, these problems have prevented many councils from performing a number of assigned tasks:

Without adequate funds, the organizations have been limited in what they could undertake. The circle was completed when the limitation on activities contributed to the reluctance of local governments to increase their financial commitments. 33

However, much of the reluctance on the part of local jurisdictions to contribute to councils has been reduced by HUD requirements. All HUD certified review agencies must have at least one-third of their work load performed by a council-controiled staff. Furthermore, all councils acting as review agencies must have a minimum financial commitment from non-federal sources. 34

Many councils have been fortunate to have funds willingly given by members and grants given by private organizations. Currently, council budgets range from under $\$ 50,000$ to the $\$ 2.4$ million of the Hetropolitan Washington Council of Governments. 35 In general the

33Hanson, on. cit., p. 9.

34U.S., HUD, Comprehensive Planning Assistance, op. cit., pp. 41 and 46.

35 Metropolitan Washington Council of Governments, "Board Okays New Budget for Action by COG Members," Regional Report, X (November-December, 1969), p.1. 
larger metropolitan area councils have budgets ranging between 300,000 and ${ }^{\circ} 1$ million. The 1969 budget of the Columbia Regjon Association of Governments was $\$ 270,000.36$ Councils obtain these funds from a variety of different sources. The sources include council-imposed dues, grants from federal agencies, state aid, grants from private foundations, special assessments on local governments for work performed, and quasi-regional taxes.

\section{Membership Dues}

One of the largest and the most common source of funds is the council members. The vast majority of councils of governments impose some form of financial commitment on all members. The specific size of the commitment usually depends on population. Once the budget has been agreed upon, it is broken down and the dues are determined according to the proportion of population residing within each jurisdiction.

A large number of councils divide the commitment into different segments before determining the specific amount required of each member. A majority of councils having only city and county members divide the total amount equally between them. Then each individual city

36 National Service to Regional Councils, Regional Council Profiles, op. cit., pp. 40-41. 
and county commitment is pro rated accorcing to population. 37

Where there are other local jurisdictions belonging to the council, these members are usually required to contribute only a minimum specified amount. In a few instances the school districts are assessed according to their individual student population.

A few councils require al]. members to contribute a certain percentage which has been previously negotiatea. in the case of the Chelan-Douglas Regional Planning Council of Wenatches, Washington, the counties are required to contribute $52.5 \%$ of the buiget, the cities $25 \%$, public utilities $10 \%$, school districts $5 \%$, port districts $5 \%$, and other districts $2.5 \%$. Within each category the local govornments contribute according to population. 38

Some councils allow local governments to provide council services instead of money. However, in all instances where some form of contribution is required, failure to provide the required commitment leads to the loss of the member's right to vote on any issue before the council.

37 Generally, the population of the counties is understooc to include unincorporated areas plus those incorporated areas which do not belong to the council.

38chelan-Douglas Regional Planning Council, Bylaws, (mimeographed, July 17, 1967), Article VIII, Section $E$. 
Federal and State Aid

Another large source of council financial aid is the federal government. A large number of different aid programs are available to councils. However, the two most important ones are the Section $701(\mathrm{~g})$ provisions of the Housing and Development Act of 1965, and the Section 205 provisions of the Demonstration Cities and Metropolitan Development Act of 1966.

The Section $701(\mathrm{~g})$ grants area available to all councils undertaking a wide variety of activities aimed at solving metropolitan and regional problems. These grants provide funds to pay up to two-thirds of the cost of the proposed work. 39 The section 205 grants also provide funds for "metropolitan development projects in metropolitan areas" performed by councils. However, these supplemental grants are limited to only one-fifth of the cost of the proposed projects. 40

The major problem with both of these grant programs is their unreliability. There is no guarantee that the needed funds will be provided when applied for, or that the funds will continie in the future. Because of this problem many councils hesitate to begin new programs based primarily upon federal grants and loans. In

39Hanson, op. cit., p. 59.

$40_{U}$.S., Demonstration Cities and Metrovolitan Development Act of 1906, op. cit., Section 205 . 
many instances, the federal government has discontinued grant and loan aid after a new program has been established and developec. This requires the local councils to provide the missing funds and pay the entire cost of the program or discontinue it.

Currently, there is a strong movement within the councils to pressure the states for adcitional aid. The majority of councils presently receiving state aid obtain it as dues from member state agencies. A few councils, however, receive significant aid directly from the state. The Regional Planning Council of the Baltimore area, for example, submits

to the State Board of Public Works its operating budget for the next following fiscal year, together with supporting schedules to show that such budget is financed as herein provided, and uron approval of such budget by the State Board ot Public Works, provision shall be made in the State budget for such ensuing fiscal year for an appropriation equal to one-third of the buciget of the Council so submitted and approved....41

\section{Other Sources}

Councils also receive funds from a variety of of other sources. The most important singie one is the individual local governments. Many councils assess the local governments for services which significantly benefit the individual members cirectly.

4lMaryland, The Annotated Code of the Public Laws of Maryland (1957 ditjon), Article 78D, Section 18 . 
Occasionally, a single local government will provide

the majority of operating funds for the entire council. 42

Finally, the other sources include funds obtained

from foundation grants, gifts, and even quasi-regional

taxes. However, these constitute only a small source

of funds, although founcation grants and other gifts

occasionally provide substantial aid to pay for specific

projects and have helped councils in their initial es-

tablishment.

While regional taxes have often been suggested, no

council currently collects a regional tax. The closest arrangement to a regional tax is used by Boston's Metropolitan Area Planning Council:

The council may expend for services and other expenses such amounts as the general court may appropriate.... The amount appropriated by the general court shall be charged as assessments on the various cities and towns comprising the district.... The state treasurer shall ... certify the amount to be assessed upon each city or town comprising the district, and said amount shall be paid by such city or town to the state treasure...43

42The Cities and County of San Joaquin Advisory Planning Association's entire budget is paid by the county government, Agreement for the Formation, (mimeographed, 1969), p. 3.

43 Massachusetts, Chapter 668 of the Acts of 1963 , as Amended Through 1969: An Act Fstablishing the lietropolitan Planning Council. Section 114 . 
CHAPTER III

COUNCIL MEMBRRSHIP

An important issue facing all councils of governments is the problem of membership.

A number of specific federal and state regulations and requirements affect the membership policies of most councils. As a general rule, all councils include the counties and large cities in their regions. In addition public agencies having areawide and regional authority are often included in the membership. Occasionally, councils discover that it is useful to include other units of local government and even private groups. This is primarily necessary when the councils are unable to meet problems for which they are responsible without the aid of these other public and private groups.l

I. STATE AND FEDERAL REQUIREMENTS

The majority of councils are not entirely free to determine their own membership. They are limited in their choices by both state and federal requirements.

INational Service to Regional Councils, Regional Council Bylaws, op. cit., p. 2. 


\section{HUD Requirements anc் Guidelines}

The Department of Housing and Urban Development, for example, has established one requirement and a number of recommended guidelines concerning the geographic area of council responsibility. In this manner the Department is $a b l e$ to cetermine minimum membership standards. In order for a council to receive comprehensive flanning assistance, as a minimum, the Metropolitan Region over which the Regional Council has authority for developing plans and programs must incluce the urbanized areas within Standard Netropolitan Statistical Areas (SFSA's) plus the contiguous area likely to become urbanized within five-ten years. 2

While HUD coes not stipulate any exacting criteria for this requirement, it coes make rough estimates. An example of this procecure occured when the Department initially refused to recognize the Columbia Region Association of Governments as a local review agency. The Department stated that the council did not meet the specified requirement until "jurisdictions representing $90 \%$ of the Portland-Vancouver metropolitan area have joined the organization." This was interpreted to mean that at least ten cities and three counties must be members of the council. 3

2U.S., HUD, Comprehensive Planning Assistance, op. cit., pr. $39-40$.

${ }^{3}$ Letter from Robert Pitts, Regional Administrator, Region VI, HUD, to NcKay kich, Executive Director, Portland Metropolitan Study Commission, Portland, Cregon, August 10, 1966, and John Painter, "Federal Funds Depend 
The Department's guidelines concerning geographic boundaries are based upon a cesire to help reduce the confusion and increase the efficiency of local government and councils of governments. The Department recommends:

(1) Where feasible, the Metropolitan Region should include urbanized areas plus the contiguous area likely to become urbanized within the long-range planning period (minimum 20 years).

(2) Where feasible, contiguous SMSA's should be included in the same lietropolitan Region.

(3) Where the state has delineated sub-state planning areas; the Nietropolitan Region should extend to the boundaries of the state-delineated planning area.

(4) Wherever feasible, bouncaries of the Hetropolitan Region should coincide with the bouncaries of the larger units of general local government, such as counties. 4

\section{Advisory Commission Recommendations}

A number of recommendations concerning council membership have also been proposed by the Advisory Commission on Intergovernmental Relations. However, these recommendations are primarily aimed at the state governments. The Advisory Commission advocates the position that councils should be given wicier latitude in establishing the limits of their authority. The model statute suggested on Regional Planning Organization," Oregonian, September 23, 1966, p. 29.

4U.S., HUD, Comprehensive Flanning Assistance,

op. cit., p. 40 . 
by the Advisory Commission

provides that the governing bodies of any two or more general purpose units of local government, such as cities and counties, may establish a regional council of public officials. It authorizes agreements to be made with governing bodies of similar units in other states in order to permit establishment of a council which could draw membership throughout the entire territory of an interstate metropolitan area. Some states might wish to broaden permissive membership to include representatives from local school districts or from the state governments.5

\section{State Requirements}

Many states have statutes which leave the question of council membership entirely in the hands of the local governments. California, for example, allows the local governments to decide the council's membership:

If authorized by their legislative or other governing bodies, two or more public agencies may jointly exercise any power common to the contracting parties, even though one or more of the contracting agencies may be located outside this state. 6

While many states allow their local governments this wide latitude in formulating council membership, a larger number are not so liberal. A majority of the states impose many forms of limitations on local council membership. These limitations are imposed through the use of both general enabling legislation and special purpose legislation.

New York and Connecticut, for example, are states

5 Hanson, op. cit., p. 40.

6California, Government Code (1963), Section 6502. 
which have built limitations and restrictions into their general enabling legislation for councils of governments. Council agreements in New York are restricted by the Regional Planning Agency Act of 1963, which limits these agreements to counties.7 Connecticut, which has no counties, limits council membership to cities, towns and boroughs and precludes membership by special districts and other governmental and private agencies. 8

Maryland and Massachusetts are examples of states which have incorporated restrictions regarding council membership into special purpose legislation creating councils. Baltimore's Regional Planning Council, created by the state legislature, has its membership (by unit and position) specifically enumerated in the legislation. The council is composed of only five counties, the City of Baltimore, and four state departments and authorities. There are no provisions in the legislation allowing for eventual expansion, nor eventual withdrawal of any members, without further special legislation. 9

While the state legislation creating Boston's Netropolitan Area Planning Council lists the initial membership, it does allow for future changes. Any other city

7 New York, General Municipal Law (1960), Articles 5 and 12. New York's Metropolitan Regional Council is a non-profit corporation and is not affected by this law.

${ }^{8}$ Connecticut, Public Act No. 511 (1965).

Mvaryland, Annotated Code, op. cit., Section 4. 
or town may also join the council if a majority of the existing members approve and

provided that any such city or town is within an area which is being urbanized and which adjoins the metropolitan area planning district and has common or related urban planning problems.10

Since its creation, seventeen other cities and towns have joined the organization. However, special legislation is still necessary for the withdrawal of any of the initial members from the council. Il

These examples indicate the variety of menbership limitations and restrictions. On the other hand, a few states have laws which prevent the creation of any official councils of governments:

For instance, in certain areas of the country local governments are considered agencies of the state and, as such, may not "join" organizations. In these instances, membership need only be redefined to apply, by position, to responsible officials who are officials or representatives appointed by the local governments. A conference of elected officials is a good example of this approach, where in the chief elected official of each jurisciction is eligible for membership in the conference is synonymous with a council of governments.12

Since the passage of the Demonstration Cities and Metropolitan Development Act of 1966, however, a majority of

10 Miassachusetts, Chapter 668, or. cit., Section 111.

IlIbid. , and the Metropolitan Area Planning Council, Metronolitan Area Planning Council, (Boston: November, 1969), (pamphlet).

12National Service to Regional Councils, Regional Council Bylaws, op. cit., p. 2 . 
states with these laws are in the process of changing them or are likely to change them to conform to federal laws and regulations.

II. COUNCIL RESTRICTIONS

In addition to the many restrictions and limitations existing in state and national legislation affecting councils, a majority of councils specify their own membership restrictions. Often these are with reference to the forms of local governments, geographic location, financial commitment, and acceptance of a written agreement. An example of these self-limitations are found in the constitution of the Columbia Region Association of Governments:

Any county or city in or near the Portland-Vancouver Standard Metropolitan Statistical Area may become a member of CRAG

1) by entering into the agreement by which CRAG has been established and

2) by complying with the requirements of CRAG's constitution and bylaws and

3) by making financial contributions as required.13

Councils occasionally will accept staff aid in place of monetary contributions, and a few councils do admit jurisdictions from outside their geographic area.14

A large number of councils require the approval of the majority of existing members before admitting

13Columbia Region Association of. Governments, Constitution, (mimeographed, n.d.) Artjcle II, Section 2.1 .

14 The Association of Bay Area Governments and the Miami Valley Council of Governments are examples of 
new members. In a few rare situations, councils may impose exceptional restrictions upon the new members. San Antonio's Alamo Area Council of Governments, for example, requires that,

in the event the number of member governmental units other than cities and counties shall in the future exceed forty-five per cent (45\%) of the total membership, the Council shall adopt by-laws restricting the addition to membership of governmental units other than cities and counties.15

\section{Types of Restricted Membership}

In addition to the general restrictions and limitation, there are many specific restrictions concerning council memberships. A majority of these refer to the voting status of special purpose local governments and public agencies. The restrictions do not prevent the "limited members" from participating in council debates, advising the council on specific programs and policies, and performing many other functions associated with council membership. The limited members, however, are usually not allowed to vote on proposals before the council.

Currently at least 17 councils are using some form of restricted membership. 16 The most common form is

councils which do allow membership of governmental units from outside their general geographic regions.

15Alamo Area Council of Governments, Articles of Agreement, (mimeographed, n.a.), Section V.

16Information complied from 46 different councils 
the ex officio membership which is used by 9 councils. The "associate" form of membership is used by only 4 councils. The "non-voting" membership is used by 2 councils and the other "affiliate", "honorary," "subscribing," "cooperative," and "inactive" forms are used only by single councils.

While these types of restricted membership are not concentrated in any single region of the country, several states have large numbers of these councils. The Pacific States and the Mid-West are home to 10 of the 17 councils using some form of restricted membership. There are only 3 councils which use more than 2 of these different types.

\section{Kinds of Member Governments}

A majority of the councils throughout the country chose to limit their regular membership to general purpose local governments. 17 Cities and counties are the only full voting members of 43 councils. Cities are the only members of 4 councils, however, one of these councils is in Connecticut, which has no counties.18

in 24 states. Statistical data from the National Service to Regional Councils, Regional Council Profiles, op. cit., council documents and letters.

17Ibid. This information, however, is complied from 89 councils in 33 states. Hartford.

18Capitol Region Council of Elected Officials of 
Counties are the sole members of 2 councils.

The Supervisors Inter-County Committee of Detroit Michigan, the forerunner of the Southeast Nichigan Council of Governments, was often listed among councils having only county members. While this was technically true, the county governing bodies were composed entirely of officials from local cities and townships. For example, in May, 1965, this committee was composed of 27 city officials and 15 township officials. However, this arrangement changed when the new council was established. 19

Other general purpose local governments, which belong to councils of governments, are townships and boroughs. These forms of local governments, however, are primarily concentrated in the Mid-Test and Pennsylvania. Townships and boroughs currently are included in 7 councils, but 2 of these are composed exclusively of townships and boroughs. 20

In adaition to general purpose local governments, special-purpose local governments are members of 29 councils. School districts are the most comnonly admitted, and belong to 18 different councils. Special districts and public utilities are also common, and belong to 15 different counci]s. A majority of the councils

19 Metropolitan Fund, Inc., Regional Organizations:

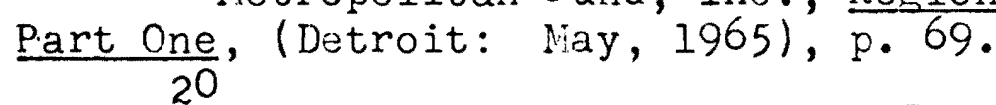

Centre Regional Council of Governments and the North Hills Council of Governinents, both in Pennsylvania. 
admitting school and special districts are located in the states of Oregon, Washington and Texas. These states contain 12 of the councils. Flanning commission are members of 4 widely scattered councils, and port commissions and authorities are members of 5 councils. The majority of the councils, which allow special-pur ose local governments to join, are usually attempting to include all governmental bodies with special taxing authority.

\section{Other Members}

A few councils are also attempting to coordinate their local policies and programs with both state and national governments. Therefore, many of these councils include officials from the se governmental bodies. State agencies are members of 7 councils and state legislators are represented on 4 councils. While federal agencies are commonly given ex officio membership on many councils, no council has any federal agency official as a full voting representative. In addition, only the Metropolitan Washington Council of Governments includes representatives from both houses of Congress as full voting representatives.

Many councils also try to include the powerful private and public associations in their policy-making bodies. The majority of the councils, in this category, 
however, allow these groups to participate only in an ex officio or associate status. Examples of these organizations are the Catholic Diocese of Pittsburgh; which is an associate member of the Allegheny Council for Intergovernmental Action, and the Denver Chamber of Commerce, which is a subscribing member of the Denver Regional Council of Governments.

A few councils, on the other hand, use these semipublic associations to help them determine the attitudes of segments of their own membership. The East-West Gateway Coordinating Council of St. Louis, for example, provides for the full voting participation on its Board of Directors of the president and vice president of the Southwestern Illinois Council of Mayors. In addition, the president of the St. Louis County Municipal Leacue serves to represent the civic community in the organization.21

The Allegheny Council for Intergovernmental Action also uses the local associations of public officials to represent governmental entities on its Executive Board. For example, the local county borough association, township commissioners association and township supervisors association, all have representation on the board, a procedure which substitutes for the direct representation

$21_{\text {East-West Gateway Coordinating Council, By-laws, }}$ (mimeograrhed, November, 1969), Article II, Section 2. 
of local boroughs and townships. 22

\section{Size of Council Membership}

In addition to the great variety in the forms of membership and the kinds of governmental units given membership, there is an equally wice range in the number of council members. Currently, the range in membership varies from 2 to 388 . The two councils with only $2 \mathrm{mem}-$ bers also differ: one has 2 city members and the other has one city and one county member. The council with the largest membership is the Penjerdel Council of Governments which has 388 members. This is more than twice the size of the second largest council. There are 35 councils with less than 10 members and 36 councils with between 10 and 30 members. There are only 17 councils with more than 30 members. 23

22 Allegheny Council for Intergovernmental Action, Bylaws, op. cit., Article VI, Section 1.

23Statistical data complied from information in the National Service to Regional Councils, Regional Councils Profiles, op. cit., council documents and letters. 
CHAPTER IV

REPRESENTATION AND VOTING

Critical factors in the decision making process of all councils of governments are the representational and voting arrangements. The determination of these factors are usually issues of much controversy.

Wany councils have been forced to develop representational and voting systems which are complicated, cumbersome and confusing. Several councils, for example, have developed different arrangements for each of their twoand three-tiered structures. A few councils permit certain members to vote only on specific issues. Others have developed more than one voting system to use in the same council body. These different arrangements are important and help to focus attention on the power relationships within councils.

\section{REPRESENTATIONAL SYSTEIS}

The representatives who occupy the policy making bodies of the councils are usually selected by their local governments under some system which takes into consideration the powers and the functions of the councils. The representatives chosen are normally those incividuals who determine and reflect their local governments' 
attitudes. Therefore, a majority of these individuals are chosen from among the governing officials of the local jurisdictions. A numbar of councils also permit non-elective officials to participate in council activities. However, the number of non-elective officials is limited by federal, state and local council requirements and restrictions.

Restrictions on Non-Rlected Member Representatives

The most important restrictions on non-elective representatives are imposed by the Department of Housing and Urban Development. The Department requires that, insofar as feasible, voting representatives from units of local governments hould be composed of elected officials or appointed chief executives responsible to elected officials.

Voting membership on the Council's policy-making body must be as prescribed by state law. If state law is not explicit, however, at least two-thirds of the voting members must be elected officials or chief appointive officials representing units of local governments which together comprise at least three-fourths of the aggregate population of the Region.1

From the beginning of the council movement the majority of councils have been primarily composed of elected local governmental officials. A number of councils do not even provide for non-elected local officials. Approximately 57 councils are composed entirely of

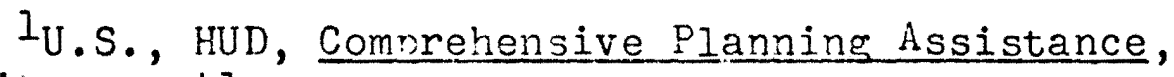
o.p. cit., p. 41 . 
elected officials. ${ }^{2}$ Another 12 councils have non-elected officials as representatives, but meet the requirements established by HUD. The majority of the remaining councils have an "unacceptable" percentage of non-elected official, representatives but are in the process of revising their representational provisions to conform to the requirements.

There is great variety in the composition of many councils. In several instances, councils are regulated by state laws predetermining much of the representation.

Connecticut state law, for example, limits council. representation to the chief electec executives of local governments or, "if such member... does not have an elected chief executive, a member of its legislative body chosen by such body to be such representative." 3

A majority of states, which have established councils through enacting special-purpose legislation, also indicate the representation. The legislation creating Baltimore's Regional Planning Council, for example, specifies the representation of each member. Baltimore is represented by both the mayor and the president of the

2 Statistical data in this chapter has been compiled from the National Service to Regional Councils, RegionaI Council Profiles, op. cit., council documents anci letters from council officials.

${ }^{3}$ Connecticut, Public Act No. 5]1, op. cit., and a letter from Dana Hanson, Executive Lirector, Lapitol Region Council of Elected Officials, Hartford, Connecticut, January 22, 1970. 
City Council. Each county is represented by its "county executive" and the chairman of the local "county council! In addition, each jurisciction has a non-elected member of the local planning board serving as a representative. Finally, the state departments anci authorities are represented by their chief appointed officials. 4 Furthermore, a majority of the councils establish self-limitations for their own representation. Normally, councils prefer representatives who are the chief elected executive officials and members of the elected governing bodies. In cases where administrative officials or their alternates must represent acninistrative agencies, provisions are made to allow for these representatives to participate.

\section{Elected Member Representation}

There is a wide variety in the range of council member representation. Obviously, the bulk of the individual representatives are from the cities and counties, which constitute the majority of most councils. The cities are usually represented by either the mayor or a member of the governing body, or by both. Several cities, however, have placed all administrative duties

4Naryland, Annotated Code, op. cj.t., Article 78D, Section 4. 
in the hands of city managers. In these instances, the city manager is usually a representative on the council, or is a member of one of the technical-advisory committees.

The counties, on the other hand, are represented normally only by a member of the county governing body. 5 In areas where counties have elected administrative officers, such as county executives or judges, provisions sometimes are made to include these officials as representatives. School districts, special districts and ports, which have elected governing bodies, usually have one of the members of the governing body as representative.

Councils which have local and state administrative agencies as members often include the chief administrative official or his chosen alternate as the agency's representative. In a few instances, the governor or his assistant is listed among the representatives of the state. Where federal agencies are members of councils, their chief local administrators are usually listed as the ex officio representatives.

5 "Representatives of county governments shall qualify as representing the unicorporated areas of the county plus those incorporated areas whose governing bodies agree to be represented by county officials." U.S., HUD, Areawide Planning Requirement, (Washington: August, .1969), p. 7. 
In an apparent desire to increase the coordination between local governments, state legislatures and councils of governments, several councils have included significant numbers of state legislators on the council policy-making bodies. Generally, these legislators are selected by the local governments and represent districts within the area of council jurisdiction. The arrangement used by the Denver Regional Council of Governments is typical. The state legislative representatives include seven State Representatives from the State Representative Districts in the Region. One State Representative shall be designated from each respective county by the board of county commissioners from the State Representative District within such county, and two State Representatives shall be designated from the State Representative Districts within the City and County of Denver by the Mayor.6

A significant variation from this procedure is used by the Regional Planning Council of Baltimore. In this case,

the Governor of the State of Maryland shall appoint a member of the Senate ... and a member of the House of Delegates of the State of Maryland, both representing legislative districts within the "Area," as members of the Council.?

A few councils also allow all. state legislators, whose districts are within council boundaries, to

6Denver Regional Council of Governments, Bylaws, (mimeographed, n.d.) Article IV, Section 3. Section 4 .

7Maryland, Annotated Code, on. cit., Article 78D, 
participate on councils. However, only the Metropolitan

Washington Council of Governments currently includes all

members of the General Assemblies of Maryland and Virginia and the Congress of the United States who represent portions of the geographical area of the National Capital Region and the members of the Committees on the District of Columbia of the U. S. Senate and House of Representatives... (Enphasis adcied) 8

\section{Lay Representation on Councils}

In 1969 the Department of Housing and Urban Development established new requirements for council representation. - Included within these requirements was the provision that lay representatives be appointed to councils:

Specific provision shall be mace to include persons from disadvantaged low income and minority groups where the selection arrangement would not result in their inclusion on the policy making body. In those instances where there is an executive committee or other similar organizational structure within the policy making body, the same representation provisions should apply. 9

The low income and minority groups were singled out for emphasis by President Nixon. In his inaugural address the President promised to help these groups, which have traditionally been ignored in the planning process. However, the Department is also encouraging

8 Metropolitan Washington Council of Governments, By-laws, (mimeographed, December 14, 1967, and amended December 11, 1969), Section III, Paragraph a.

9U.S., HUD, Areawide Planning Requirements, on. cit., pp. 7-8. 
all community groups, such as professional and business organizations, to participate in council decision making.10

While no council of governments presently fulfills the Department's requirements on lay representation, at least seven councils provide for some lay representation. The East-West Gateway Coordinating Council of the St. Louis area comes closest to satisfying this requirement. Currently, the council has

six "Regional Citizens" selected for one year terms from among the Black Community, the Business Community, the Labor Community, the Educational Community, and the Religious Community sectors....

Each year at the conclusion of the November meeting of the Board of Directors the appointing officials will caucus and allocate the community sectors to the various appointing officials (or caucuses)....11

The appointing officials are the mayors of St. Louis and East St. Louis, the governors of Missouri and Illinois, the Supervisor of St. Louis County, Missouri, and the governing board of Madison County, Illinois. Each of these officials appoints one lay representative.12

The governors of Maryland and Massachusetts also appoint citizen representatives to councils in their.

10Letter from William Fuller, Senior Assistant for Congressional Relations, HUD, to Senator Robert Packwood, October 29, 1969.

ilEast-West Gateway Coordinating Council, By-laws, op. cit., Article II, Section 2.

12 Ibid. 
states. The governor of Maryland, for example, appoints to Baltimore's Regional Planning Council two citizens residing within the council area.13 The governor of Massachusetts appoints twenty-one lay representatives to Boston's Metropolitan Area Planning Council.14

The Executive Board of Dallas-FortWorth's North Central Texas Council of Governments also has the authority to appoint a number of non-elected citizens from each county in the area to the council. The exact number of representatives is cietermined by a simple populationweighted formula: one citizen per 250,000 population and up to five representatives from any one county.15 Nonelected governmental officials and members of the publicat-large are also appointed by the Board of Trustees of the 0-K-I Regional Planning Authority of Cincinnati. 16

The General Assembly of Detroit's Southeast Michigan Council of Government may also appoint, upon the recommendation of its executive committee, as many as seven citizens, who serve as non-voting at-large advisors.

13Maryland, Annotated Code, op. cit., Article 78D, Section 4 .

14Massachusetts, Chapter 668, op.cit., Section 109.

15North Central Texas Council of Governments, Bylaws, (Revised), op. cit., Section VI.

160hio-Kentucky-Iridiana Regional Planning Authority, Policy and Procecure Manual, op. cit., p. 1. 
"The citizens to be considered for these seats should be recognized because of their civic or public interests and accomplishments as 'regional statesmen. " 17

Finally, the arrangement developed by Baton Rouge's Capital Region Flanning Commission, which includes nonelected citizens on its policy-making bodies, differs from these other approaches toward lay representation. The citizens on this council serve as regular nembers of each jurisdiction's delegation, instead of being at-large, areawide observers. They are selected by each local city council or parish 'police jury.' The number of citizens selected from each jurisdiction is determined by a simple population-weighted formula. 18

\section{Geograrhic Versus Interest Group Representation}

Previous to the adoption of the HUD regulations on low income and minority group representation, few persons in these categories served on council policy-making bodies. However, a majority of councils had lay representatives on their technical-advisory committees, and a few used them as advisors on the policy-making bodies. Of course, council decision-making processes were dominated by the local government officials.

17 Southeast Michigan Council of Governments, By-laws, (mimeographed, June 29, 1967), Article IV, Section 5 .

18 Capital Region Planning Commission, By-laws and Rules of Procedure, (mimeographed, as amended September 16 , 1968), Article III, Sections A-C. 
In conflicts within councils between community desires and regional needs, the local government officials almost invariably respond to community demands. Interest group representatives, on the other hand, are generally not concerned with boundaries; their interests cut across such lines.

While interest groups currently have little influence over council decisions, this situation may change as a result of the strong HUD requirements on interest group representation, with respect to minority and low income groups.

There is, of course, a strong possibility that stronger interest group representation may develop a real split between the regionally-minded representatives and the more geographically-criented governmental officials. Interest groups are not hampered by community pressures in the way government officials are, and, consequently, should be able to develop a more regional bias. The more geographically-oriented representatives must always consider how each decision will affect their constitutencies. If these two approaches can work together, the chance for regional planning and coorcination will be greatly improved.

\section{VOTING SYSTEMS}

Closely related to the critical problems of representation are the equally critical problems concerning 
voting. There is an increasing concern within councils over the entire voting process. This is farticularly apparent where there are wide population differences among the constituencies of council members. Responding to many of these problems, several forms of voting arrangements have been developed by various councils.

There are basically three different broad classifications of voting arrangements. They are the "one unit, one vote," the "weighted vote" or "proportional vote," and the "one man, one vote" systems. While there are many special arrangements in use, they can be placed in one of these classifications.

"One Unit, One Vote"

The "one unit, one vote" system is the most popular and is used by most councils. Currently over 55 councils use this arrangement. It is the easiest method to determine and the most acceptable to the members. For these reasons it is the most popular with new councils.19

Under this system, in. governmental unit has one voting representa$u+v e$ regardless of population, size of financial contribution, or other consideration. Occasionally, this scheme is modified to the extent that all units of government of the same type have an equal number of voting representatives but not necessarily the same number as do other types of governments. For

${ }^{19}$ Letter from James Dowden, Assistant Director, National Service to Regional Councils, Washington, D.C., January 27, 1970. 
instance, a council may agree that each county has two votes and each municipality has one. 20

This basic approach facilitates the simple handling of the non-controversial business before the council. In several instances, tris simple voting arrangement has enabled new councils to avoid many of the complex procedural problem by ignoring juridictional differences and emphasizing the need to build a consensus during the early stages of council cevelopment. However, this same approach can develop into a major barrier to the broadening of future council responsibilities. This is especially true in metropolitan areas having lar and powerful core communities but a predominance of smaller governmental units. "The large jurisdictions are generally unwilling to take suboroinate positions when matters of importance are being decicied." 21

Weighted or Proportional Voting

Many councils, attempting to avoid these problems, have turned to "weighted or proportional" voting systems. These systems are a basic attempt to form a compromise between the needs for council consensus and greater representation of the larger jurisdictions. At least 27 councils of governments are currently using some form of

20 James Dowden, A Summary of Regional Council Voting Systems, (mimeographed, December 23, 1969), p. 1 . ${ }^{21}$ Harman, op. cit., p. 14 . 
"weighted or proportional" voting.

There are several different possible arrangements within this basic approach. One common avenue is to give each member an equal number of representatives on the council. However, each representative's voting strength varies according to some formula negotiated among the membership. This form gives some representatives on the council multiple votes and, consequently, significant influence. Another avenue is to allow some members more than one representative with each representative having a single vote. 22

The voting strength is usually the result of a compromise based upon each member's constituent population, financial contribution, and form of government.23 The counties and larger cities are normally given a significant voting advantage. The smaller governmental entities combined usually are given only a few votes.

"One Man, One Vote" 24

The "one man, one vote" approach is similar to the

22 This is not the same as the one man, one vote approach since a jurisdiction's multiple representation is not necessarily based on population.

230 ccasionally, counties are arbitrarily given a greater voting strength in councils than other forms of local governments.

24 The legal questions concerning "one man, one vote" and councils of governments are discussed in detail in. Chapters VI and VII. 
weighted-proportional voting systems, but is based solely on population. The major differences between these forms is one of degree. While the weighted-proportional systems are based upon rough estimates and negotiated results, the one man, one vote system is an attempt to use only population, determined by the latest census information. While no council presently has a true one man, one vote system, several councils use systems which attempt to emulate this approach. The council approach which most clearly resembles this system is used by Baton Rouge's Capital Region Planning Commission. In this instance, the parishes gain an additional representative for every 10,000 of population in excess of 30,000 . The cities, on the other hand, receive an additional representative for every 5,000 population in excess of 10,000 population. 25

While the representational and voting strengths of cities and counties are difficult to determine, it would be virtually impossible to use this same approach for the special purpose governments and administrative agencies without distorting the council's relationships.

\section{The Aopeal of Population-Based Systems}

An increasing number of councils are beginning to examine the possibilities of developing population-based

25capital Region Planning Commission, Bylaws, op. cit., Article III, Sections B-C. 
representational and voting arrangements. While much of this interest is being generated by the larger jurisdictions, there is also significant pressure from other groups, to alleviate much of the gross inequities found in the one unit, one vote approach. Furthermore, while the federal government does not require a weighted or proportional representational-voting system, it does recommend that "the distribution of voting power on the council policymaking body should be proportional to population. "26

Several councils have undergone shifts in their representational or voting arrangements. I'he Columbia Region Association of Governments, for example, made a major change in its voting system in 1968 as a concession to the City of Fortland. The city wanted an arrangement essentially proportional to population, but was forced to settle for a weighted voting system. The city gained significant voting strength in the council's Executive Committee, although its vote in the General Assembly was unchanged. 27

More recently, the City of Cleveland, a member of the Northeast Ohio Coordinating Agency, is seeking through court action to require the Coorcinating Agency to operate on a one man, one vote basis.

26 U.S., HUD, Comprehensive Planning Assistance, op. cit., p. 41 .

27 "CRAG Adopts Weighted Voting Plan 13-5," Oregonian, October 18, 1968, p. 1 . 


\section{CHAPTER V}

\section{REPRESENTATION AND VOTING: SELECTED SYSTEMS}

In attempting to alleviate the problems of geographic differences within regions, population differences between member jurisdictions, and the variety in the types of council members, many councils have developed arrangements which are extremely complex and confusing. 1 Huch of this complexity is the result of a cesire to balance these different factors and to develop safeguards which can help to relieve the many local suspicions and widespreaci distrusts.

\section{GEOGRAPHIC FACTORS}

While there are relatively few inter-state councils, most of these are located within the larger metropolitan regions. In addition to the kinds of problems facing other councils, these councils also have problems arising from their intier-state nature.

Ionly single-bocied councils and the executive committees of the two- and three-tiered councils are discussed here in detail. Only the most important aspects of the other council bodies are discussed. Since a majority of the councils using two- and three-tiered structures have develored mocified or unusual arrangements, these systems are discussed separately from the basic models examined in Chapter IV. 
Louisville, Kentucky, Metropolitan Area

The arrangement developed by the Falls of the Ohio Metropolitan Council of Governments of the Louisville metropolitan area is an example of the simple approach to inter-state representational and voting arrangements. The Kentucky and Indiana jurisdictions are given equal representation and voting strength on the council. Each state's city and county delegations have six representatives and six votes to distribute between them. There is no attempt made to compensate the Kentucky jurisdictions for their more populous constituencies. 2

\section{St. Louis Metropolitan Area}

A similar inter-state balance is maintained on the Board of Directors of the East-West Gateway Coordinating Council of the St. Louis metropolitan area. Within this inter-state balance, however, exists an extremely complex intra-state arrangement. There are seven representatives from the local governments in each state, two non-voting state department administrators, one inter-state agency official and six regional citizens: a total of 14 local, 4 non-voting state, 1 inter-state, and 6 regional representatives.

The Missouri delegation is composed of the mayor

2Letter from Wilbert Watkins, Director, The Falls of the Ohio Metropolitan Council of Governments, Louisville, Kentucky, December 30, 1969. 
and president of the Board of Aldermen of St. Louis, the presiding judge of each county, and the president of the St. Louis County Municipal League. The IlJinois delegation, on the other hand, reflecting a greater areawide concern, is composed of the mayor of East St. Louis, the chairman of the board of commissioners of each county, the president and vice president of the Southwestern Illinois Council of Mayors, and the president of the Southwestern Illinois Metropolitan Area Planning Commission. The states are represented by the chief engineers of the highway departments, and the directors of the Illinois Department of Business and Economic Development and the Missouri Department of Community Affairs. The chairman of the Bi-State Development Agency, a non-profit public corporation, is also a nember of the board. Moreover, there are six regional representatives representating the Black, Business, Labor, Educational, and Religious Communities. 3

The basic inter-state balance was created in 1965 as an attempt to alleviate the widespread distrust of the St. Louis leadership. Although the Missouri portion of the council's area has approximately 77 per cent of the population, the council leaders found that the only

3East-West Gateway Coordinating Council, By-laws, op. cit., Article IV, Section 2. See Chapter IV for the method of selection of the regional lay representatives. 
acceptable compromise was equal representation and voting for the delegations from the two states. 4

\section{New York Metropolitan Area}

Other inter-state councils have found it necessary to negotiate geographic and population differences. New York's Metropolitan Regional Council, for example, has developed an arrangement which considers both of these factors. The council's boaro' of directors is composed of nine members from the three states in the region. The jurisdictions in New York select 4 representatives, the jurisdictions in New Jersey select 3 representatives, and the municipalities in Connecticut select 2. Each representative has only one vote.5 In this manner no single state delegation has sufficient strength to control the board.

Moreover, New York City, the largest single member jurisdiction, has only one representative on the board. However, this representative also serves as the council's. permanent chairman. This arrangement is most successful device developed by the council to ensure the necessary participation of the large number of suburban

4Letter from Wallace Altes, Administrative Assistant, East-West Gateway Coordinating Council, East St. Louis, Illinois, January 6, 1970.

5 Metropolitan Regional Council, Metropolitan Regional Council: A Voluntary Organization to Strength Local Government, (pamphlet, n.d.). 
jurisdictions in the metropolitan area.

\section{Portland Metropolitan Area}

A few inter-state councils have been able to develop representational and voting arrangements which emphasize only the areas population patterns. The system used by Portland's Columbia Region Association of Governments is one example. In this instance the Executive Committee of the council is composed of 9 representatives, who cast a total of 16 votes.

The largest city, Portland, has one representative, who is entitled to 4 votes. Each county also has one representative, who casts 2 votes. The cities in each county, other than Portland, share 1 representative, but cast only 1 vote. 6 Under this arrangement the largest city and the counties can control the committee. In addition, there is a basic overall city-county balance.

\section{POPULATION FACTORS}

Many councils have significant population variations between their local jurisdictions. Usually these are between the large, populous core cities and the multitude of smaller suburban jurisdictions. A few councils even have several competing population centers. The arrangements developed by councils with these problems

6Columbia Region Association of Governments, Constitution, op. cit., Article IV, Section 4.2. 
also range from the very simple to the complex. Examples of these arrangements have been discussed in the previous section.

Many councils with population disparities attempt to emphasize the large jurisdictions by giving them additional representation and voting strength. However, these arrangements are not always satisfactory.

\section{Cleveland Metropolitan Area}

A case in point is the Northeast Ohio Areawide Coordinating Agency (Cleveland area). The council's Steering Committee is composed of the four Agency officers, the máyors of Cleveland and Akron, a representative from Cuyahoga County, and at least one representative from each of the other three counties. Each representative has only one vote on the committee.7

This arrangement, however, has been attached by the City of Cleveland as not reflecting the area's population patterns. There is strong city pressure to adopt a more precise one man, one vote system for the council. Currently, Mayor Stokes of Cleveland is testing in court the legality of the present system, and indirectly; the application of the recent Supreme Court "one man, one vote decisions" to the voting arrangements of councils of

7Northeast Ohio Areawide Coordinating Agency, "NOACA'S Organization," NOACANE:rS, I (Deceriber, 1969), pp. 2-3. 
governments. 8

Puget Sound Regional Area

Other councils also use various forms of "spotlighting" similar to the Cleveland area council's, but to a greater iegree of satisfaction. In the case of the Puget Sound Governmental Conference, there are several large, competing population centers within the area. However, each of the major centers is located in different counties. Therefore, the arrangement developed for the Conference's Executive Committee includes one representative from each county and one from the largest city in each county. In addition, the other municipalities together share one representative. Each representative on the committee has one vote. 9 Although there are significant differences in the size of the major cities, each has an equal voice.

\section{Pittsburgh Metropolitan Area}

Occasionally councils encompassing a small geographic area but with a large number of member governments find it necessary to develop unusual arrangements. In the case of Pittsburgh's Allegheny Council for Intergovernmental Action, it was found necessary to group

8Letter from Anthony Toth, Program Director, Northeast Ohio Areawide Coordinating Agency, Cleveland, Ohio, January 5, 1970.

9Puget Sound Governmental Conference, Perspectives: 1968 Annual Report, (Seattle: May, 1969), p: 3 . 
member jurisciictions into different blocs.

The council's Executive Committee is composed of one representation from Pittsburgh and one from Allegheny County. The cities of Clairton, Duquesne, and McKeesport are grouped together and share one representative. The 42 member townships are also grouped together, but they. share one representative from the Allegheny County Association of Township Commissioners and one from the Allegheny County Association of Township Supervisors. The 81 boroughs members, on the other hand, share only one representative from the Allegheny County Boroughs Association. Each of these representatives has one vote. In addition to these governmental representatives, large segments of the general public are represented by officials from both public and private agencies. These agencies range from the Pennsylvania Economy League (Western Division) to the Catholic Diocese of Pittsburgh.10

\section{Dallas-Forth Worth Metropolitan Area}

A slightly different kind of arrangement is used by the North Central Texas Council of Governments. In this instance the council's Executive Committee is composed of the three council officers, the immediate past president, five directors of the Regional Planning

10 Allegheny Council for Intergovernmental Action, Bylaws, op. cit., Article VI, Section 1. 
Commission, 11 and two citizen representatives. Two of the Commission's directors must represent the cities of Dallas and Fort Worth and at least one other representative must be from a county. The directors are selected by the entire Planning Commission. Citizen representatives on the Executive Committee are selected by and from the citizen representatives on the Commission, with the provision that one citizen must be from either Dallas or Tarrant Counties. Each representative is entitled to only one vote.12 While the core cities have a significant voice on the committee, the voice is not decisive, nor proportional. The committee, as a whole, on the other hand, is given a strong sense of direction by the council's past and present leadership.

\section{Washington Metropolitan Area}

Several councils have developed weighted representational and voting systems which give the larger jurisdictions significant strength. The largest and most important council to use the weighted vote is the Metropolitan Jashington Council of Governments. This arrangement was developed in the council's Executive Committee and not in the General Assembly. The Assembly is

11This Regional Planning Commission, and its relationship to the council, is discussed in Chapter II.

12 North Central Texas Council of Governments, Bylaws (Revised), op. cit., Section IV. 
composed of all members of the governing bodies of all member jurisdictions anò certain state and Congressional legislators. As a result of this arrangement, the smaller jurisdictions have significant voting advantage in the assembly since all representatives have one vote.

The larger jurisdictions are compensated by the weighting of each of their votes by population in the more important council bodies. The council's Board of Directors, for example, is composec of nineteen representatives. One representative is selected from each jurisdiction with over 100,000 population, 13 and the other representatives are divided among the other participating local governments and state and Congressional legislators. The weighted vote is:

(1) On a vote on the budget or amendment to it.... (2) On a vote on any other matter, weighted voting may be called for by a majority of members of the participating governments on the Board.

(3) Any question for which weighted voting has been called shall be determined by the majority of the members of the participating governments present and voting. For this purpose, each participating government shall have one vote for each 25,000 population, and the next major succeeding portion thereof, $\ldots$ except that any participating government whose jurisciction has a population of less than 25,000 shall have one vote.

(5) Board members from the Virginia Generai Assembly, the Maryland General Assembly, and the United States Congress, shall be excluded from any weighted vote. 14

13Washington, D.C., is consiciered as both a city and a county by the Council, and has two representatives and two votes on non-weighted voting questions.

luivetropolitan Washington Council of Uiovernments, 
As a result of this arrangement, the larger jurisdictions have a considerable voting advantage over the smaller members. In adoition, while the state and national legislators have a voice in the discussions, they do not have a vote on any controversial matters when the weighted vote is invoked.

The composition of the board's Steering Committee and its voting arrangement, on the other hand, is neither complex nor confusing. The large jurisdictions have virtually complete control. The committee is composed of one person from each jurisdiction over 100,000 population and one person representing all jurisdictions under 100,000 population. Moreover, all issues are decided by a simple majority of all representatives present and voting. 15

\section{San Francisco Bay Regional Area}

Occasionally, councils develop arrangements which can be extremely complex. When the Association of Bay Area Governments changed its representation and voting system in 1968, the final arrangement was both complicated and confusing.

While the Association's General Assembly has

By-laws, op. cit., Section V with amendments. See Chapter II for a more detailed discussion of the council's organization.

15 Ibid. 
remained bicameral with a city-county balance, the Executive Committee has undergone several serious changes. The comnittee was originally slightly balanced in favor of the cities. However, currently the committee is strongly controlled by the cities; the three largest cities control just under one-third of the representatives. The committee is composed of thirty three representatives including the council's president and vice president. The City and County of San Francisco has five representatives, Oakland has three representatives and San Jose has two representatives. Alameda arid Santa Clara Counties have two representatives each, and the cities in each county has two representatives. Marin, Napa, Solano, 16 and Sonoma Counties each have one representative, as do the cities in each county. Contra Costa and San Mateo Counites, on the other hand, each have one full-time representative and one adoitional representative who rotates between the cities and the counties. The cities also have one full-time representative and one additional who alternates on a yearly basis with the counties. Each representative has only one vote.17

16 Solano County, which is authorized one representative and one vote, is currently not a member.

17Association of Bay Area Governments, Bylaws, op. cit., Article V, Section A. 
While the cities can control this Executive Committee, their influence could be negated in the General Assembly by the counties. Since all cecisions must ultimately be approved by a majority of both cities and counties in the General Assembly, it is doubtful that strong city blocs would attempt to override strong county objections in the Executive Cómmittee. The decisions of the Executive Committee have rarely been overturned by the General Assembly.

\section{OTHER ARRANGTMENTS}

Frequently, councils which have special problems and internal factors must adopt special arrangments which emphasize their peculiarities.

\section{Boston Metropolitan Area}

The system developed by Boston's Metropolitan Area Planning Council is an example of one council's attempts to emphasize these local factors. The council was established by the state legislature with a number of specific membership blocs. These membership blocs have been also incluced in the council's Executive Committee and reflect the different attitudes of the blocs. The committee includes the four council officials.

of the remaining twenty members, five shall be elected from the representatives of cities; provided that at least one such member elected is a resident of the city of Boston; five shall be elected from the representatives of towns; five 
shall be elected from the citizens appointed by the governor; and five shall be elected from the ex officio members.j.8

As a result, the larger jurisdictions are not given any additional representation or voting advantage, and, other than Boston, may not even be represented on the important Executive Committee. Since all representatives have one vote, the citizen and ex officio members are not down-graded nor are they relegated to the impotent status of advisors. Since the council was formed by the state, there is a continuing desire to represent an areawide outlook instead of the local parochial interests of the individual jurisdictions.

\section{Chicago Metronolitan Area}

A more common arrangement is used by Chicago's Council of Governments of Cook County, Illinois. The council's General Assembly is strongly balanced by the use of the "concurrent majority bloc voting system" which essentially requires the approval of a majority of the representatives of at least three of the four membership blocs: cities and villages; school districts; non-school special districts; and townships and the county. This balance is between the different forms of governments. The Executive Committee is balanced to reflect the geographic areas within the county.

18Massachusetts, Chapter 668, op. cit., Section 113. 
The Executive Committee of the council is heavily weighted in favor of the smaller municipalities. The bociy is composed of twenty one representatives. The city of Chicago and Cook County each has one representative. The cities and villages over 30,000 population share six representatives and the cities and villages under 30,000 also share six representatives. However, "within each category a representative should be drawn from each geographic section of the county." The elementary and secondary school districts have one representative. The townships share three representatives and are selectec from each geographic region. The special cistricts have two representatives. Each representative on the committee has only one vote.19 The result of this arrangement is that the two largest, most important and metrovolitan-oriented jurisdictions have little control over the decisions reached by the committee or the council. While neither Chicago nor Cook County has strength in accord with thejr population and influence, the smaller municipalities have numerical superiority and can control the comrittee. However, since any three membership blocs must approve a decision in the General Assembly, it is possible to create a ciead-lock if Executive Committee decisions are made simply by cities.

19Council of Governments of Cook County, Illinois, By-laws, (mimeographed, November 20, 1968), Section V. 
IV. SUMMARY

These twelve examples of the different forms of representational-voting arrangements used by many of the more important metropolitan area councils of governments can give only a small indication of the large variety of possible local solutions. They demonstrate both the great flexibility and diversity of council power structures. Largely because of this elasticity, many local councils are able to overcome the many small but important obstacles facing metropolitan cooperation and coordination. This same elasticity, however, can also hinder the council's development. Many councils are in continual change due to the many internal pressures. Many councils have found that their existing arrangements have proven faulty and in need of change. Some councils are in the process of reorganization. Two examples of these councils are the Penjerdel Council of Governments of Philadelphia and the Council of Governments of Cook County, Illinois. Whether a council succeeds will partially be determined by the success of its internal representational voting arrangements and its ability to accommodate the interest of dissident members 


\section{CHAPTER VI}

REPRESENTATION AND VOTING: ONE MAN-ONE VOTE?

An issue which can greatly change the entire future development of councils of governments is the question of the legality of the present council representational and voting arrangements. This issue has significant immediate and long term consequences to all councils. The immediate problems concern the constitutionality of existing council systems. If the systems do not conform to the law, what changes are necessary? If they do currentIy conform, will future changes be necessary when councils are able to gain greater responsibilities. Or will the possibility of future representational and voting changes deter the development of councils?

\section{I. "EQUAL PROTECTION"}

Beginning with the Baker v. Carr decisionl, the Supreme Court has gradually extended the meaning of the Equal Protection Clause of the Constitution to include all levels of government. The Court has specifically applied the equal representation interpretation to all general purpose local governments in the Avery v. Midland County,

IBaker v. Carr, 369 U.S. 186 (1962). 
Texas decision in 1968.2

The Avery Decision

The defendants in the Avery case had maintained that the county's governing body did not perform a legislative function and that the body did not represent people, but geographic districts. They maintained, furthermore, that according to prior Court decisions the equal representation requirements did not apply to the county's body.

The Supreme Court ruled, however, that the county's governing body, the Commissioners Court, is

assigned some tasks which would normally be thought of as "legislative," others typically assigned to "executive," or "acministrative" departments, and still others which are "judical." In this regard Midland County's Commissioners Court is representative of most of the general purpose governing bodies of American cities, counties, towns, and villages. 3

When the State apportions its legislature it must have due regard for the Equal Frotection Clause. Similarly, when the State delegates lawmaking power to local governments and provides for the election of local officials from districts specified by statute, ordinance, or local charter, it must insure that those qualified to vote have the right to an equally effective voice in the election process. 4

Our decision today is only that the Constitution imposes one ground rule for the development of arrangements of local government: a requirement that units with general governmental powers over

\footnotetext{
2 Avery v. Midland County, Texas, 390 U.S. 474 (1968). 3390 U.S. at 482 . 4390 U.S. at 480 .
} 
an entire geographic area not be apportioned among single-member districts of substantially unequal population. 5

Until the Avery case the Court had apparently limited its application of the equal representation principle to general purpose governments with significant legislative powers. This decision, however, extended the principle to all general purpose governments, without regard to their legislative nature. The major impact of this case was felt in nearly all the cities and counties throughout the country.

The Hadley Decision

Finally, on February 25, 1970, in Hadley v. Junior College District of Metropolitan Kansas Citv, Missouri, the Supreme Court extended the application of the principle to all forms of elected government. The Supreme court ruled that,

while there are differences in the powers of different officials, the crucial consideration is the right of each qualified voter to participate on an equal footing in the election process.

We therefore hold today that as a general rule whenever a state or local government decicies to select persons by popular election to perform governmental functions, the Equal Protection Clause ... requires that each qualified voter must be given equal opportunity to participate in that election. 6

This case has apparently ended the basic controversy

5390 U.S. at 485 .

6Hadley v. Junior College District of Metropolitan Kansas Citv, Missouri, $90 \mathrm{~S}$. Ct. 791 (1970) 
over whether an elected government is administrative or legislative in nature, and whether it is general or special purpose local government. All elected governments are expected to comply with the equal representation principle. There remains the question: Does this principle apply to governmental entities with appointed governing bodies performing legislative functions?

II. "NOTHING ... TO PREVENT EXPERIMENTATION"

Currently these rulings do not appear to apply to councils of governments. While the majority of councils are composed of elected local officials, the representatives are not elected by the populace nor do they directly represent people, but governments. The representatives are essentially appointed by their respective local jurisdictions to represent governmental interests.

The councils, moreover, are not legislative governmental entities. While their decisions have an ul.timate impact upon regional planning, they are primarily voluntary advisory bodies.7

\section{The Sailors Decision}

Their status, furthermore, is protected by several Supreme Court decisions allowing for governmental

7While they are voluntary bodies, the larger members are prevented from withdrawing due to coercive factors enforced by HUD which regulate all review agencies. 
experimentation with regard to local government. The major case establishing this principle was Sailors v. Boarc of

Education of Kent County, Michigan. ${ }^{8}$ The Supreme Court. ruled:

no Constitutional reason why state or local officials of the nonlegislative character involved here may not be chosen by the governor, by the legislature, or by some other appointive means rather than by election....

Viable local governments may need many innovations, numerous combinations of old and new devices, great flexibility in municipal arrangement to meet changing urban conditions. We see nothing in the Constitution to prevent experimentation. At least as respects nonlegislative offices, a State can appoint local officials or elect them or combine the elective and the appointive systems as was cone here.... Since the choice of members of the county board did not involve an election and since none was required for these nonlegislative officies, the principle of "one men, one vote" has no relavancy.9

\section{Reassertion in the Hadley Decision}

This principle was amain emphasized in the Hadley decision in February, 1970:

We have also held that where a State chooses to select members of an official body by appointment rather than election, and that choice does not itself offend the Constitution, the fact that each official does not "represent" the same number of people does not deny those people equal protection of the laws.... But once a state has decided to use the process of popular elections and "once the class of voters is chosen, and their qualifications specified," we see no constitutional way by which equality of voting power may be evaded.10

ESailors v. Boarc of Education of Kent County, Michigan; 387 U.S. 105 (1967).

9387 U.S. at 108 anci 110.

10 Hadley v. Junior College District, $90 \mathrm{~S} \mathrm{Ct.} 791$. 
Application of Equal Representation to Councils

According to a number of reliable sources, the equal representation requirements do not apply to councils of governments. For example, the Department of Housing and Urban Development studied the question and the result was that,

two or three years ago the HUD General Council opined that COGs which were voluntary advisory bodies were not affected by the Supreme Court decisions concerning the representativeness of local governing bodies. As they take on operating functions, however, courts may find that the one man, one vote rule applies to COGs.II

Furthermore, the National Service to Regional Liouncils also examined the problem. It concluded:

as we understand the current court cases, the Supreme Court and certain local courts have ruled that in those instances where direct governmental services or activities of government cause a disruption or influence the lives of the citizens of that government, then the decision-making process shall be accessible equally to all citizens. In effect, then, with respect to the councils of governments, until such time as the council of governments becomes the implementary agency for its decisions affecting the population of the region, we would assume it would not be legally necessary for the council to have a population based voting system.12

Nevertheless, since the Court has not specifically viewed such a case, the question of whether the one man, one vote concept applies to councils remains unanswered.

${ }^{1 l_{L}}$ Letter from Nicholas $F$. Thomas, Lirector, Division of Planring Assistance, HUD, February 6, 1970.

12Letter from C. James Lowien, Assistant Lirector, National Service to Regional Councils, Washington, D.C., January $27,1970$. 
CHAPPER VII

CONCLUSION

Within the short sixteen year history of the council of governments movement many developments have taken place which have had a significant impact upon the governmental situation in metropolitan areas. Beginning in 1954 with the establishment of the Supervisors Inter-County Committee in the Detroit metropolitan area, the movement has grown to encompass the majority of metropolitan areas and many other areas as well.

\section{Development}

The early councils originated as local efforts to alleviate regional and metropolitan governmental problems and conditions. When the first few councils began to prove their value, public and private organizations in other locations began to encourage the establishment of councils. As early as 1961, the Advisory Commission on Intergovernmental Relations suggested the council concept as a viable alternative to the ineffectiveness of local governments in metropolitan areas. In adition, by 1962 , the American Municipal Association and the National Association and the National Association of County officials were providing joint services to help existing councils 
and to encourage the development of additional ones. Eventually these two associations formed a new organization, the National Service to Regional Councils, designed to guide and nourish regional councils throughout the country.

While earlier federal programs helped finance councils of governments, the first major legislation specifically designed to encourage their development did not emerge until the passage of the Housing and Development Act of 1965. Section $701(\mathrm{~g})$ of the Act authorizes metropolitan area coordinating agencies to apply for grants covering as much as two-thirds of the cost of several different activities and programs. Encouraged by this source of funds, many local governments hastened to establish councils.

In 1966, Congress passed the Demonstration Cities and Metropolitan Development Act. For the first time the national legislature directed the establishment of metropolitan areawide agencies instead of simply encouraging their development through financial incentives. The major coercive factor of the Act is the requirement for review and comment by a recognized metropolitan review agency before grants or loans to local governments will be approved. In addition, incentive is provided through the authorization of grants up to one-fifth of the cost of accepted projects. These grants are supplemental to other 
federal grant programs, provided that the total federal contribution to the cost of the project does not exceed 80 per cent.

Under the impetus of the Demonstration Cities Act, the vast majority of metropolitan areas, which did not yet have review agencies, created councils of governments. Since the passage of the Act in 1966, over 100 new councils have been created.

External Factors and Influences

Currently, the majority of councils throughout the country are strongly influenced and directed by many factors beyond their local area and sphere of control. These factors help both to further council development and responsibilities and to circumvent courcil initiative and priorities.

Among the most important external factors and influences affecting councils are the many federal and state requirements, restrictions and procedures. While the purpose of most of these factors is to augment councils authority and extend council capabilities, they also inhibit council development.

One requirement established by HUD, for example, limits each metropolitan area to one local review agency. The purpose of this limitation, obviously, is to provide for greater metropolitan coordination through a single areawide agency. Many regions, however, have more than 
one metropolitan organization attempting to coordinate governmental activities. There are competing local councils, as well as local councils competing with state and inter-state agencies. In areas with competing entities, the fecieral government has chosen to recognize and support the state and inter-state bodies to the detriment of the local councils of governments.

In many cases the federal government has attempted to push many of its goals and policies upon the local councils. For example, in 1969, it adopted a policy requiring the representation of low-income and minority groups on all review agencies. While this change may be ultimately desireable and eventually necessary, it has altered the equilibrium of a majority of councils. It has introduced a raoical change into many councils by compelling the representation of nongovernmental officials. Moreover, this required change has acded many new problems and conflicts to the already overwhelmed councils.

While the council concept originated as a voluntary effort to improve coordination and cooperation among metropolitan area governments, the federal government is exhibiting more and more direct control over councils. The position of the federal agencies is strengthened by the adoption of standaris and regulations which councils must meet. In this manner the federal government is able to enforce its goals and policies indirectly on local 
governments. These pressures of the federal government have a strong tendency to divert council facilities, limit or derail projects desired by council members, and add unnecessary barriers to council operations. Furthermore, they serve to complicate existing problems and aggravate local conflicts and suspicions.

Several state governments have also attempted to impose their goals and policies on the local councils. Although there is indication in many areas that state interest and pressures are increasing, these attempts have not been too common. Currently, the councils which are most strongly influenced by state governments are the Baltimore and Boston area councils, which were established by special state legislation.

In Oregon the Governor has "directed" the local governments within each of the State's fourteen administrative districts to join and make use of existing councils of governments or to establish councils where none exists. Unfortunately the State acted without first gaining the ear of local officials. By not determining local desires and needs, the state has fomented unnecessary local opposition. Communities in two state administrative areas have refused to cooperate with the State on this matter.I While the State has sufficient pressure to ensure that a

IThese are in Baker, Klamath and Lakeview Counties. Interview with A. McKay Rich, Executive Director, Portland Metropolitan Study Commission, April 14, 1970. 
majority of local communities and existing councils will comply with the State's desires, much of this controversy could have been averted by a better understanding of local problems. The need is great for better state-local cooperation, but it must be handled with an awareness of local priorities, desires and needs.

While the federal and state governments must have a strong influence in the councils, their influence must be tempered with understanding. They should continue to regulate councils and provide the incentives necessary to aid council development. However, they should refrain from hindering local initiative and drive.

The federal and state governments must keep to a minimum the number of standards, regulations and procedures which inhibit local interests and retard council development. The councils are already faced with their share of major problems which have prevented the vast majority of them from becoming truely effective instruments of metropolitan cooperation and coordination.

\section{Council Problems}

Councils face many kinds of problems. Some are common to all councils, while others are mainly local in nature.

Councils of governments have generally been unable to achieve concrete solutions to regional problems, although many have undertaken important research and 
planning efforts. Furthermore, while a majority of councils were created as a result of federal legislation and regulations which virtually require metropolitan planning agencies and provide many financial incentives, there is strong pressures within Congress to repeal these laws and regulations.

Several congressmen have accused federal officials of using the council device to create "super governments": The anti-metropolitan sentiment was strong enough in the House of Representatives in 1968 to achieve an amendment to a housing bill deleting section 204 requirements. Fortunately the amendment was dropped from the final draft of the bill proposed by the Senate-House Conference Committee and adopted by the Congress. 2

A number of council problems concern structural defects. Several councils, including the Penjerdel Council of Governments, the Miami Valley Council of Governments, the Metropolitan Regional Council, and the San Diego County Comprehensive Planning Organization, have already undergone major reorganization attempts. The council of Governments of Cook County, Illinois, and the Mississippi-Arkansas-Tennessee Council of Governments, are currently in the process of making important structural changes.

Councils have also found themselves unable to 2Harman, op. cit., p. 13. 
perform satisfactorily because of inadequate funding and staff aid. A few councils have even found that promised monies have not been forth coming. The Chelan-Douglas Regional Planning Council, for example, has not been able to collect revenues promised by members, a problem compounded by HUD regulations which limit the use of existing funds. The result is that "at this point in time the organization is largely a 'paper' one."3

Councils have become the arenas of strong conflicts between different levels of government. The Penjerdel

Council of Governments is one of these arenas:

It seems that the large urban counties are battling with various functional state bureaucracies (principally the highway departments) for the control of emerging regional agencies. These regional agencies ... are relatively new, have a fuzzy outlook and potentially can wield a great deal of power. The net effect is that the Penjerdel Region has a fragmented, amorphous and confusing regional government or sovernance. 4

Councils are plagued with the problems of "public invisibility, the voluntary nature of the councils, and the tendency for council activities to become static and fail to develop." 5 Moreover, the projects of genuine significance tend to be controversial and too often fail

3Letter from Villiam Phillips, Associate Planner, Joint Planning Office, Wenatchee, Washington, November $14,1969$.

4Letter from Jack R. Nelson, Acting Executive Director, Penjerdel Council of Governments, Philadelphia, Pennsylvania, January 19, 1970.

5Barnes, "Coping With Metropolitan Problems," op. cit., p. 3 . 
to garner sufficient support. Too many councils find themselves unable to maintain the interest of members.

\section{Council Success}

The determination of a council's success or failure can be an extremely difficult process. Few council accomplishments can be listed in terms of roads or buildings constructed, or even in terms of legal powers gained or laws enacted. A council's value and

effectiveness must be measured in terms of regional issues defined, policies proposed and approved, achievement of a regional process of change, degree of coordination among local governments, degree of involvement of local elected officials and community leaders, and number of challenges met. 6

While there are not many councils which can be considered major success stories, many councils are laying the groundwork necessary for future success. Among the more successful councils can be counted the Metropolitan Washington Council of Governments and the North Central Texas Council of Governments.

Successful councils are characterized by flexibility and adaptability. The North Central Texas Council of Governments is a good example of a councils which has been adaptable to a changing situation and has moved from public invisibility to visibility.

While public invisibility is an asset during a 6Richard Hartman, "Editorial," Public Management, (January, 1969), p. 3 . 
council's early development, there comes a time when there is a need for public acceptance and awareness.7 The North Central. Texas Council has taken several steps to ensure and increase public awareness. It has developed citizen advisory and technical committees. It has contracted with the Texas Research League to find ways to increase citizen participation, and it has gained the support and participation of key community leaders. 8

The result of this active effort to develop visibility and awareness is public understanding of the council's place in the regional community. This in turn has enabled the council to get the funding needed to operate in a wide range of fielcs.9

Other councils not as successful as the North Central Texas Council of Governments also have a high degree of flexibility and adaptibility, but have not been able to overcome their problems. Either their members have not been sufficiently able to put aside the many suspicions to develop cooperation and create a truely regional outlook,

7 "Public" includes not only the general public, but elected and appointed officials and influential community leaders.

8Barnes, "Coping With Metropolitan Problems," op. cit., p. 3 .

While the North Central Texas Council has been successful in at least many of its enceavors, there are several areas of potential difficulties. The region has most of the common problems of rural-suburban-urban disputes, large numbers of political jurisdictions, and local suspicions and distrust. Ibj.., p. $r$. 
or the councils themselves have not been able to find satisfactory formulas for success.

Whatever the problems,

the fundamental issue is whether councils of governments will develop into meaningful instruments of political decision-making. Most of these organizations lack, at this stage of development, the characteristics of political efficacy required of any organization which intends to deal with the difficult problems of urban areas. A major test of councils will be whether elected officials meeting together in a voluntary association can actually take decisive action on political problems which are both complex and difficult.10

\section{One-Man-One-Vote}

A major obstacle which could retara or derail councils concerns questions of representation and voting. More precisely, does the "one man, one vote" concept apply to appointed councils of governments which perform administrative and legislative functions? The general opinion is that the concept does not presently apply. However, if councils assume additional responsibilities, wili major changes in their basic representation-

al and voting systems be necessary?

The potential effects constitute a paradox. On the one hand, one man-one vote for the country will undoubtedly encourage a greater cooperative role for the country and this is consistant with the basic purpose of COGs in facilitating metropolitan cooperation, coordination and/or joint action. On the other hand, the present decision-making structure of most COGs is badly malapportioned in the direction of one governmental unit-one vote basis, rather than one man-one vote basis. If the COGs

10Harman, op. cit., pp. 15-16. 
should begin to make authoritive decisions which are significant enough to cause the Supreme Court to apply the one man-one vote principle to COGs, we can expect the voluntary structure of their political support to fall apart almost overnight. This is not to say that reapportionment of COGs would inevitably cause their abolition, but only that the principle of voluntarism in COGs is incompatible with one man-one vote representation in COGs. 11

How much and what kind of representational experimentation the court will permit remains to be seen. Certain clues emerge from the ... discussion, but they remain only clues. For example, entities whose representational arrangements do not conform to the principle of equal representation may be excepted, if a part or all of the membership is appointed; or if thej.r responsibilities are so narrowly defined in the underlying statutes or charter as to render them "administrative" rather than "legislative"; or if the system appears to be a constructive, fair-minded experiment, whose formula represents a workable compromise among opposing groups, and is necessary to solve important metropolitan problems.12

Should councils of governments develop to a point where the equal representation concept become applicable, one of several alternatives might take place. One would be the retardation of councils back into a completely voluntary and essentially ineffectual basis. Another would be the enactment of special legislation by state governments mandating the participation of local governments in councils. Without this external pressure the smaller cities and counties would probably not choose

11 Daniel Grant and Robert McArthur, "'One-Man-Vote' and County Governments," The George Washington Law Review, XXXVI (May, 1968), pp. 775-7.

12 Scott and Bollens, op. cit., p. 102 . 
to give up their autonomy and "equality." However, if local governments are forced to join councils, either by state laws or federal regulations, this could supply the force necessary to transform the councils into meaningful limited-purpose metropolitan or regional governments.

What is the Future of Councils of Governments?

Although the future is acutely unpredictable, councils of governments are likely to play an important role in the development of our metropolitan communities. Their true roles are unascertainable until some important questions can be answered.

Probably the most important single question is what the future role of the federal government will be. In the past it has served as the major inspiration for the development of the council movement. The most important function, the review powers of councils, has been also required by federal regulation:

Section 204 gives councils of governments their most important political tool by granting them the power to review local development plans and administrative programs.... The fact that Congress came close to dropping Section 204 leaves the future of the policy in doubt. The uncertainty is heightened by the change in national administrations. The councils of governments movement gained momentum during the Democratic administration. A change in emphasis by a Republican administration committed to expanding the role of the states could reverse or retard the council-of governments system.13

13Harman, op. cit., p. 16. 
Another important question is whether councils will continue to be unwilling or unable to deal effectively with the major controversial issues of the day. Councils to date have been largely blind to the major social problems facing all urban communities. They have contented themselves with dealing with relatively safe and unemotional issues, such as land-use planning, 14 public works coordination, administrative coordination and cooperation, and metropolitan and regional communications. While the se are important, other major issues concerning discrimination and inequality, education, poverty, and housing, have been largely ignored.

While councils acting as review agencies for the federal government are required to develop programs in these fields, their efforts to date are not promising. Introduction of low-income and minority representation on council policy-making bodies could alter this picture. There is an excellent possibility for major reevaluation of many of the present priorities. Until councils are capable and willing to enter these important fields in earnest, their influence can not be pervasive, and their potential will remain restricted.

What is the future of councils of governments? Will

14 While land-use planning is potentially an extremely emotional and explosive issue, councils teno to work with it only on a superficial level. 
they eventually evolve into some form of metropolitan or regional government? No council has become such a government. However, several councils have been studying this possibility. 15

Will the councils evolve into an extension of the state governments on a regional level? Several states are currently examining this possibility. However, none has acted to implement it.

Or will the future see numerous organizations reflecting the complications of the federal system in all its diversity? This last development appears to be the most likely one. While there has been no widespread interest expressed by council officials or officials from the three levels of government to change councils into new levels of metropolitan government nor to make councils extensions of the states, there has been much interest and discussion in experimenting with the council concept to meet regional conditions and problems. There is also strong interest in working with all levels of government, but on a voluntary and mutually productive basis.

15see Chapter II for the proposal made by the Association of Bay Area Governments. 
Banfield, Edward C., ed. Urban Government: A Reader in Acrinistration and Folitics. Kevised edition. New York: The Free Press, 1969.

Dixon, fiobert G., Jr. Democratic Representation: Reaovortionment in Law and Politjcs. New York: Oxford University Fress, 1908 .

Harman, Douglas B. "Councils of Governments and Metropolitan Decision-ifaking," The Municipal Yearbook 1969. Washington: Internaticnal City ivanagers Association, 1969, pp. 10-i6.

Schinid, Warren. "The ABAG Case: Coordinating Common Problems in a Regional Setting," Where Governments Weet: Emerging patterns of Intergovernmental Relations. Willis D. Hawley, ed. Berkeley: Institute of Gov ernmental Studies, 1967, pp. 75-8.8.

Scott, Stanley, ad. Local Government in a Changing World: A Seminar for City and County lianagers 1965-igou. Berkeley: Institute of Covernmental Studies, 1967.

Scott, Stanley, ard Bollens, John C. Governing a Metrovolitan Region: The San Francisco Bay Area. Berkeley: Institute of Governmental Studies, 1968.

\section{PRRIODICALS}

"Area Cooperation on the $U_{n}$-Swing," The Local Government Newsietter, XXI, No. 5 (January, 1970), p. 1. (Published by the Insitute for Urban rolicy and Ackministration, University of Pittsburgh).

Barnes, Philip W. "Coping With Fetropolitan Problems: The North Central Texas bouncil of ioverrments," Fublic Affairs Corment, XIII, No. 3 (Nay, 1967), pp. 1-4. - "Councils of Governments in Texas: Changing Pecieral-Local Relations," public Affairs comment, XIV, 
No. 4 (July, 1968), pp. 1-4.

Buck, Thomas. "A Concept of Order: Metropolitan Planning Does not Mean Surer-Government," Commerce, (December, 1968), reprint.

Cox, James L. "Feceral Urban Development Policy and Metropolitan Washington Council of Governments," Urban Affairs Quarterly, III, No. I (September, 1967), pp. 75-94.

Finlayson, Jucith. "Council of Governments: What and Why Are They?" American County Government, XXXII, (April, 1967), pp. 20-25.

"From Manager to COG Director: Journey to the Unknown," Public Management, (January, 1969), reprint.

Grant, Daniel R.G., and McArthur, Robert E. "One-Man-OneVote' and County Governments: Kural, Urban and Metropolitan," The George Washington Jaw Review, XXXVI, No. 4 (March, 1968), pp. 700-.777.

Hanson, Royce. "They Can't Legislate or Tax," Nation's Cities, V, (June, 1967), rp. 5-7.

Hartman, Richard C. "Editorial," Public Management, (January, 1969), reprint.

Huth, Ora. "Activity Continues on Bay Area Plans," National Civic Review, LVIII, (July, 1969), pp. 317-320.

Jones, Victor. Metropolitan Detente: Is It Politically and Constitutionally Possible" The George Washington Law Review, XXXVI, No. 4 (March, 1968), pp. 74I759 .

Mathewson, Kent. "A Growing Movement," National Civic Review, LVII, (June, 1968), pp. 298-302.

Ray, James F. "Coordination of Regional Planning and Development Organizations: The Challenge and the Texas Response," Public Af'iairs Comment, XIII, No. 6 (November, 1967), $\mathrm{Fp} \cdot 1-4$.

Scheiber, Walter A. "Evolution of a COG: Tackling the Tough Jobs," oublic Management. (Reprinted as the "COGs: Governing for the 2lst Century," by the International City lianagers Association, January, 1969). 
Citizens Ieague. Citjzens League Report: A Metrorolitan Council for the Twin Cities Area. Hinneapolis: February 9, 1967 .

Cockrell, Lila. Report or the Alamo Area Council of Governments. Presented to the San Antonio City Council, January 7, 1968. (Mimeographed).

Committee of One Hundred. A Proposal for a Voluntary Council of Governments in Southeast Michigan. Detroit: June, 1966.

Dowden, C. James. A Summary of Regional Council Voting Systems. Memorandum presented to the National Service to Regional Councils, December 1.3, 1969.

Huth, Ora. Regional Organization in the San Francisco Bay Area--1970. Berkeley: Institute of Governmental Studies, April 18, 1970. (Mimeographed). Background Faper No. 1 for the Regional Conference--1970.

Institute for Local Self Government. ABAG Appraised: A Quinquennial Review of Voluntary Regional Cooperative Action Through the Association of Bay Area Governments. Berkeley: December, 1905.

Jones, Victor. Rerresentative Local Government: Neighborhood to Region. Paper presented to the National Conference on Government, Philadelphia, Pennsylvania, November 11, 1969. (Nimeographed).

Mathewson, Kent. Workshop on Voluntary Multi-Furpose Regional Organizations. Frepared for the American Municipal Association. Washington: 1961. (Mimeographed).

Metropolitan Fund, Irc. Regional Organizations: Part I. Vetroit: May, 1965.

Nathan, Harriet, and Scott, Stanley, ed. Toward a Bay Area Regional Organization: Conference Rerort. Berkeley: Institute of Governmental Studies, 1969.

National Association of Counties and the National League of Cities. Proceedings of the Workshop on Voluntary City-County Regional Cooreration. New Orleans: July, 1966 . 
National Association of Counties and the American Municipal Association. Voluntary Uity-County Regional Cooperation: A Collection of Exhibits Featuring Such Information as By-laws, Organizational Arrangements, State Enabling Laws, Vorkshop Liscussions, etc. as Taken From the Experiences of $5 x i s t i n g$ Regional City-County Cooperative Groups. Nashington: July, 1963.

National Service to Regional úouncils. Key Federal Programs. Special Report No. 7. Washington: July, 1968. (Pamphlet).

- Organizing a Regional Council. Special Report No. 3. Washington: May, 1968. (Pamphlet).

- Program Implementation. Special Report No. 6. Washington: July, 1968. (Pamphlet).

- Regional Alternatives. Special Report No. 2. Washington: July, 1968. (Pamphlet).

- Regional Council Bylaws. Special Rejort No. 4. Washington: May, 190ह. (Pamphlet).

- Regional Council Directory. Washington: February, 1969.

igegional Council Profiles. Washington: March, 1969.

- Regional Councils and States. Special Report No. 8. Washington: November, 1968. (Pamphlet).

- Regional Program Frimer. Special Report No. 5. Washington: July, 1968. (Pamphlet).

- Regional Review: An Fxperiment in Intergovernmental Coordination. Washington: May 1, 1969. (Booklet).

Northeast Illinois Planning Cormission. Manual for Intercommunity Councils. Report No. 8. Chicago: October, 1964 .

Portland Metropolitan Study Commission. Voluntary Regional Conference of Local Governments: A Recommendation From the Preliminary Comprehensive Plan. Portlanc: October 9, 1965. 
DOCUIENTS

COUNCILS OF GOVERNNENTS

Alamo Area Council of Governments. Articles of Agreement. San Antonio, Texas, n.d. (Mimeographed).

By-laws. San Antonio, Texas, January 31, 1906. (Mimeographed).

- Program 1970. San Antonio, Texas, December, 1969.

Allegheny Council for Intergovernmental Action. Bylaws.

Pittsburgh, Pennsylvania, November 25, 1969. (Nimeographed).

Association of Bay Area Governments. Bylaws. Berkeley, California, October 13, 1967. (Mimeographed).

- Members and Representatives to the Association. Berkeley, California, September, 1969. (Mimeographed).

- Pronosed Budget: 196́-1970. Berkeley, California, approved by the Executive Comittee December 19, 1968. (Mimeographed).

Association of Central Oklahoma Governments. Dylaws. Oklahoma City, Oklahoma, n.c.. (Mimeographed).

Capital District Regional Planning Commission. A Procram for Regional Development in the Canital District of New York State. Albany, December, 1967.

Capital Region Planning Commission. Dy-laws or Rules of Procedure. Baton Rouge, Louisiana, September 16, 1968. (Nimeographed).

Capitol Region Council of Elected Officials. By-laws. Hartford, Connecticut, October 26, 1966. (Mimeographed). - $\frac{\text { C.R.C.E.O. Background Report. Hartford, Connect- }}{\text { icut, Aligust 1, 1968. (Mimeographed). }}$

- Third Annual Report. Hartford, Connecticut, hay 30, 1969. (Nimeographed). 
Central Lane Planning Council. A Creative Approach to District Planning 1970. Eugene, Oregon, January 28, 1970 .

Chelan-Douglas Regional Planning Council. Áreement. Wenatchee, Washington, July 17, 1967. (Mimeographed). ivvlaws. Wenatchee, Washington, July 17, 1967. (Mimeographec).

Cities and County of San Joaquin Advisory Planning Association. Agreement for the Formation of the Cities and County of San Joaquin Advisory Planning Association. Stockton, California, 1969. (Nimeographed).

Columbia Region Association of Governments. Annual Progress Report January, 1968. Portland, Oregon, January, 1968 .

By-laws. Portland, Oregon, April 27, 1967. (Nimeographed).

- Constitution. Portlana, Oregon, n.d. (Mimeographed).

- CRAG Annual Report 1968. Portland, Oregon, February 4, 1969.

Council of Fresno County Governments. Bylaws. Fresno, California, September 24, 1969. (Mimeographed).

- Proposed Joint Powers Agreement. Fresno, California, September 24, 1909. (Mimeographed).

Council of Governments of Cook County, Illinois, By-laws. Chicago, Illinois, November 20, 1968. (Mimeographed).

Denver Regional Council of Governments. Annual Report, 1968. Denver, Colorado, January, 1969.

- Bylaws. Denver, Colorado, n.d. (Mimeographed).

East-Viest Gateway Coordinating Council. Articles of Incorporation. Tast St. Louis, Illinois, Lecember 8 , 1965, with amencments through October 25, 1967. (Mimeographed).

- By-laws. East St. Louis, Illinois, December \&, 1965 , with amendments through November 6, 1969. (Mimeographed). 
Kings County Regional Planning Agency. Cooperative Agreement for the Formation of the Kings County Regional Planning Agency. Hanford, California, Ápril 2E, 1957 . (Mimeographed).

- Resolution No. 1: Rules for Transaction of Business. Hanford, California, May 24, 1967. (Mimeographed).

Metropolitan Atlanta Council of Local Governments. Bylaws. Atlanta, Georgia, June 7, 1968. (Mimeographed).

- MAGLOG 1968 Annual Report. Atlanta, Georgia, April, 1969.

Metropolitan Regional Council. Annual Report 1968. New York, 1969.

Metropolitan Washington Council of tovernments. By-laws. Washington, D.C., December 14, 1967. (Mimeographed).

- Proposed Amendments to the Articles of Incorporation and By-laws. Viashington, D.C., adopted December 11, 1009. (Mimeographed).

- Report and Recommendation of the Special Committee on Representation. Prepared by Valter A. Scheiber, Washinton, D.C., October 7, 1969. (Mimeographed).

Miami Valley Council of Governments. Sample By-laws. Prepared by the Montgomery County Mayors and City Managers Association and the Community Research, Inc., Dayton, Ohio, December, 1967. (Pamphlet).

Mid-Cumberland Council of Governments. A Proposed Role for the Mid-Cumberland Council of Covernments. Prepared by David H. Grubbs, Nashville, Tennesee, November, 1968 .

Mid-Willamette Valley Council of Governments. Charter and Agreement. Seizem, Oregon, July 25, 1967. (Mimeographed).

Mississippi-Arkansas-Tennessee Council of Governments. Bylaws. Memphis, Tennessee, n.d. (Mimeographed). - First Annual Report 1968. Memphis, Tennessee, n.d. (Mimeographed). 
North Central Texas Council of Governments. Bylaws (Revised). Arlington, Texas, n.d. (Mimeographed). - State of the Region Report 1969-19'70. Arlington, Texas, n.d.

Ohio-Kentucky-Inciana Regional Planning Authority. Policy and Procedure Manual: Section 204 Review. Cincinnati, Ohio, Niarch, 1969.

Piedmont Triad Council of Governments. Amended Bylaws. Greensboro, North Carolina, June 27, 1969. (Himeographed).

Puget Sounci Governmental Conference. Perspectives: 1968 Annual Report. Seattle, Washington, May, 1969.

Regional Conference of Elected Officials, Inc. Proposed Revision of Bylaws of the Regional Conference of Elected Officials, Inc., (To Be Known as the "Penjercel Council of Governments. Inc."I). Philadelphia, Pennsylvania, adopted October 27, 1969. (Mimeographed).

Regional Planning Council. By-laws and Rules of Procedure. Baltimore, Maryland, n.d. (Mimeographed).

Sacramento Regional Area Planning Commission. Annual Report of Progress: 1968-1969. Sacramento, California, September 18, 1969.

Shasta Counties and Vities Area Planning Council. Annual Report, Feriod Ending June 30, 1969. Prepared by Benjamin A. Harris, Redoing, California, November 6, 1969. (Mimeographed).

Southeast Michigan Council of Governments. Bylaws.

Detroit, Michigan, December 13, 1968. (Mimeographed).

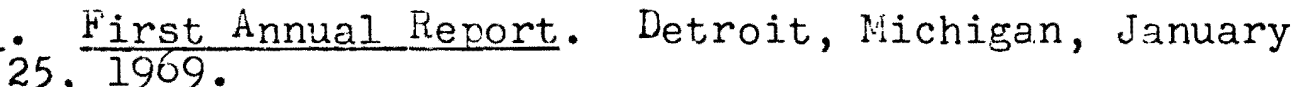

- SEMCOG 2nd Annual Rerort. Detroit, Michigan, January 31, 1970.

Southern California Association of Governments. Southern California Assuciation of Governments: The Region and the Association 1968. Los Angeles, California, February, 1969. 
Whatcom County Council of Governments. Articles of Association. Bellingham, Washington, October 6, 1969; (Mimeographed).

By-laws. Bellingham, Washington, October 6, 1969. (Mimeographed).

Yakima County Conference of Governments. Agreement. Yakima, Washington, December 2\&, 1966, and revised January 20, 1969. (Nimeographed).

- Rules of Procecure. Yakima, Washington, June 26, 1967. (Mimeographed).

\section{PUBLICATIONS}

\section{COUNCILS OF GOVERNMENTS}

Fast-West Gateway Coordinating Council. What You Should Know About Your East-west Gateway Coorcinating Council. East St. Louis, Illinois, n.d. (Famphlet).

Maricopa Association of Governments. "MAG: A Council of Governments," MAG Regional Review, I, No. I (June, 1969), p. 1. (Phoenix, Arizona).

Metropolitan Area Planning Council. Metrorolitan Area Planning Council. Boston, Nassachusetts, November, 1969. (Pamphlet).

Metropolitan Regional Council. Metropolitan Regional Counci1: A voluntary Organization to Strengthen Local Government. New York, n.d. (?amphlet).

Metropolitan "ashington Council of Governments. "Board Okays New Budget for Action by COG Nembers," Regional. Report, $Y, N_{0}$. 6 (November-lecember, 1969), pF. I-2.

Mid-Cumberland Council of lovernments. The Mid-Cumberland Council of Governments - The Hic-Cumberland Develorment District. Nashville, Tennessee, n.d. (Pamphlet).

Northeast Ohio Areawide Coordinating Agency. "NOACA's Organization," NCACAN TS, I, No. I (Decerber, 1969), pp. 203. (Cleveland, Ohio). 
Rogue Valley Council of Governments. Municipal Yearbook Questionaire. Medford, Oregon, May 21, 1969. - RVCG. Medford, Oregon, June, 1969. (Pamphlet).

San Diego County Comprehensive Planning Organization. Comprehensive Planning Organization of the San Diego Region. San Diego, California, n.d. (Pamphlet).

Tampa Bay Regional Planning Council. Tampa Bay Regional Planning Council. St. Petersburgh, F'lorida, n.d. (Booklet).

\section{DOCUMENTS}

FEDERAL GOVERNWENT

Hanson, Royce. Metropolitan Councils of Governments. U.S., Advisory Comrission on Intergovernmental Relations Report No. M-32. Washington: U.S. Government Printing Office, August, 1966.

Martin, hoscoe C. Metrorolis in Transition: Local Government's Adantation to Lhanging Urban Needs. Prepared for the U.S., Housing anc Home Finance Administration. Washington: U.S. Government Printing Office, 1963.

U.S., Advisory Commission on Intergovernmental Relations. Alternative Approaches to Governmental keorganization in Metronolitan Areas. Report No. A-11. Washington: U.S. Government Printing office, June, 1962. - Fiscal Balance in the American Federal System, Vol. I, and Vol. II: Metropolitan Fiscal Lisparities. Report No. A-31. Washington; U.S. Government Printing Office, October, 1967.

- Government Structure, Organization, and Planning, in Metropolitan Areas. Keport No. A-5. Washington: U.S. House of Representatives, Committee on Uovernment Operations, Conmittee Print, 87th Congress, Ist Session, July, 1961.

A Handbook for Interlocal Agreements and Contracts. Report No. M-29. Washington: U.S. Government Printing Office, March, 1967. 
- Intergovernmental Responsibilities for Water Supply and Sewage Disposal in Metropolitan Areas.

Report No. A-13. Washington: U.S. Government Printing Office, October, 1962.

- Metropolitan America: Challenge to Federalism. Report No. M-3I. Washington: U.S. House of kepresentatives, Committee on Governmental Operations. Committee Print, 89th Congress, 2nd Session, 0ctober, 1966.

Performance of Urban Functions: Local and Areawide. Report No. N-2I Revised. Washington: U.S. Government Printing Office, September, 1963.

- The Problem of soecial Districts in American Government. Report No. A-22. Washington: U.S. Government Printing Office, Nay, 1964.

- State Constitutional ano Statutory Restrictions Upon the Structural, sunctional, anc fersonnel Powers of Local Government. Report No. A-12. Washington: U.S. Government Printing Office, October, 1902.

- Urban and Rural America: Folicies for Future Growth. Report No. A-32. Washington: U.S.: Government Printing Office, April, 1968 .

U.S., Department of tiousing and Urban Development. Areawide Planning Requirements. Uircular No. MD 64.15.1. Washington: August 28, 1969.

- Comprehensive Planning Assistance, Handbook I: Guidelines Leading to a Grant. Handbook No. MD 6041.1. Washington: Narch, 1969.

CONGRESSIONAL ACTS

U.S., Demonstration Uities and Metrocolitan Development Act of 1966 , 8C Stat. 1202 .

U.S., Federal-Aid Highway Act of 1962, 76 Stat. 1145.

U.S., Housing Act of 1954 , 68 Stat. 590.

U.S:; Housing Act of 1956, 70 Stat. 109i.

U.S., Housing Act of 1957, 71 Stat. 294. 
U.S., Housing Act of 1959, 73 Stat. 654.

U.S., Housing and Urban Development Act of 1968, 82 Stat.

$$
\text { U.S. SUPREME COURT CASES }
$$

Avery v. Midland County, Texas, $88 \mathrm{~S} \mathrm{Ct.} 1114 ; 390$ U.S. 474 $(1968)$.

Baker v. Carr; 82 S Ct. $691 ; 369$ U.S. 186 (1962):

Dusch v. Davis, $87 \mathrm{~S}$ ct. 1554; 387 U.S. 112 (1967).

Hadley v. Junion College District of Metropolitan Kansas City, Missouri, $90 \mathrm{~S} \mathrm{út.} 791$ (1970).

Reynolds v. Sims, 84 S Ct. 1362; 377 U.S. 533 (1964).

Sailors v. Board of Education of Kent County, Michigan, 87 s Ct. 1549; 387 U.S. 105 (1967).

\section{STATE LAWS}

California. Government Code (1963), Section 6502.

Connecticut. Public Act No. 511: An Act Concerning Regional Councils of Elected Officials, $(1905)$.

- Public Act No. 378: An Act Concerning Regional Councils of Elected Officials, (1907). Maryland. The Annotated Code of the Public Laws of MaryRegional Planning Council.

Nassachusetts. Uhapter 668 of the Acts of 1963, as amended through 1969: An Act Establishing the Metropolitan Area Flanning Louncil.

New York. General Municipal Law (1960), Articles 5 and 12 . 
NEWSPAPERS

"Charter, Bylaws CK'd for Council of Governments," MailTribune, October 1, $1968, \mathrm{p} .1$. (Article refers to the Rogue Valley (ouncil of Governments, Medford).

"CRAG Acopts Weighted Voting Plan 13-5," Oregonian, October 18, $1908, \mathrm{p} .1$.

"CRAG Agrees to Reapportion Txecutive Board Voting kights," Oregonian, June 1, $1968, \mathrm{p} .1$.

"Delay in Planning Heló Expensive to County," Oregonian, September 22, 1966, p. 35.

"Editorial," Fresno Bee, March 25, 196\%. Reprint.

Mershon, Andrew. "Fortland Opens kight for Stronger Voice," Gregonian, February 3, 1968, p. \&.

Painter, John. "Fecieral Funds Depend on Regional Planning Organization," Oregonian, September 23, 1966, p. 29.

"Revised CRAG Constitution Demanded by Portland Council," Oregonian, January 24, 1968, p. 17.

"Sewer Work Delayed as Grants Held Back," Oregonian, June $24,1966, \mathrm{p} .20$.

Spence, Morton. "City Moves for Bigger CRAG Role 'Disaproints' Official.s in Area," Oregon Journal, January $25,1968, \mathrm{p} .9$.

\section{CORREST ONDTNCE}

Altes, Mallace, Acministrative Assistant, East-West Gateway Coordinating Council, East St. Louis, Illinois, Correspondence of January 6, 1970 .

Anderson, John, Jr., Executive Director, Knoxville Area Council of Local Governments, Knoxville, Tennessee. Corresfondence of Decernber 14, 1969.

Barnes, Philip W., Research Associate, Institute of Public Affairs, The University of Texas at Austin, Austin, Texas. Correspondence of February 18, 1970. 
Boley, Jean, Secretary, Yakina County lanning Department, Yakima, Washington. Correspondence of November 12, 1969.

Chin, James S.K., Assistant Director, Thatcom County Council of Governments, Bellingham, Washington. Corresponcience of November 5, 1969.

Cox, Lindsay W., Executive Director, Piedmont Triad Council of Governments, Greensboro, North Carolina. Correspondence of December 31, 1909.

Debolske, John J., Secretary, Maricopa Association of Governments, Phoenix, Arizona. Correspondence of January $21,1970$.

Divelbliss, H.H., Executive Secretary, Santa Barbara CountyCities Area Planning Council, Santa Barbara, California. Uorresponoience of October 27, 1969.

Dodson, Lance, Professional Staff, Lake-Porter County Regional Transportation and Planning Commission, Crown Foint, Indiana. Correspondence of January 14, 1970 .

Dowden, James, Assistant Director, National Service to Regional Councils, Wishington, D.C. Corresponcence of January 27, 1970.

Doyle, Phil A., Director, Council of Governments of Cook County, Illinois, and the Director, Center for

Research in Urban Government, Loyola University, Chicago, Illinois. Correspondence of February 6, and February 17, 1970.

Emerson, Victoria, Administrative Assistant, San Diego County Comprehensive Planning Organization, San $\mathrm{D}_{\text {iego, }}$ California. Corresfondence of October 3C, 1969.

Forst, James L., Planner II, Central Iowa Regional Planning Commission, Des Piloines, Iowa. Corresroncience of January 7, 1970.

Fuller, Villiam H., Senior Assistant for Congressional Relations, HUD, Washington, D.C. Corresponcence with Senator Robert Packwood, Fortland, Oregon, October $29,1969$.

Garvin, Dan, Associate Plamner, Merced County Association of Governments, Nerced, California. Correspondence of October 23, 1969. 
Gray, Sidney L., Executive Lirector, Capital Region Planning Commission, Baton Rouge, Louisiana. Lorrespondence of December 29, 1969.

Hamilton, Ranòy H., Executive Director, Institute for Local Self ciovernment, Berkeley, California. Corresponcence of January 19, 1970.

Hanson, Dana, Executive Director, Capitol Region uouncil of Elected Officials, Hartford, Connecticut. Correspondence of January 22, 1970.

Harris, Benjamin A., Secretary, Shasta Counties and Cities Area Hanning Council, Redding, California. Correspondence of November 5, 1969.

Jeffery, Donald C., Deputy City Attorney, Portland, Oregon. Correspondence with Earl Bradfish, Assistant to Commissioner Francis Ivancie, Portland, Oregon. December $19,1967$.

Kelly, Michael J., Assistant to the Uity Manager, Oakwood, Ohio. Correspondence of December 31, 1969.

Kolcierie, Ted, Executive Director, Citizens League, Minneapolis, Minnesota. Corresponcience of February 12, 1970.

Kvarsten, W.J., Director, Mid-Willamette Valley Council of Governments, Salem, Oregon. Correspondence of October 21, 1969.

Mahoney, J.K., Deputy County Administrator, Lounty of San Joaquin, Stockton, California. Correspondence of October 22, 1969.

McCray, Lewis E., Executive Lirector, Tuscaloosa Area Council of Local Governments, Tuscaloosa, Alabama. Correspondence of December 31, 1969.

Meisner, Donald M., Director, Siouxland Interstate Metropolitan Flanning Council, vioux City, Iowa. Corresponcience of December 30, 1969.

Miller, Davici C., Aaministrative Assistant, Association of Central Oklahoma Governments, Oklahoma City, Oklahoma. Correspondence of January 16, 1970.

Neison, Jack R., Acting Executive Director, Fenjerdel Council of Governments, Philadelphia, Pennsylvania. Ciorrespondence of January 19, and ilarch 10, 1970. 
Philips, William L., Associate Flanner, Joint Planning office, Wenatchee, Washington. Correspondence of November $14,1969$.

Pitts, Robert, Regional Administrator, Region VI, HUD, San Francisco, California. Correspondence of August 10, 1966 with A. McKay Rich, Executive Director, Portland Metropolit an Study Commission, Portland, Oregon.

Rall, Ellis, Information Officer, Denver Regional Council of Governments, Denver, Colorado. Correspondence of December 29, 1909.

Ray, James F., Assistant Director, Institute of Urban Studies, The University of Texas System, Arlington, Texas. Correspondence of February 25, 1970.

Ries, John C., Assistant Director, Institute of Government and Pubiic Affairs, University of California at Los Angeles, Los Angeles, California. Correspondence of February $24,1970$.

Ronningen, Johan, Publications and Technical Services, Uity and County of Honolulu, Hawaii. Correspondence of January 6, 1970.

Saylor, Don J., Director, Clark County Regional Planning Council, Las Vegas, Nevada. Correspondence of January 5,1970 .

Scott, Stanley, Assistant Director, Institute of Governmental Studies, University of Cálifornia, Berkeley, California. Correspondence of January $2 \xi$, and September $17,1970$.

Smith, Neil G., Fxecutive Director, Mississippi-ArkansasTennessee Council of Governments, Memphis, Tennessee. Correspondence of February 9, 1970.

Thomas, Nicholas P., Lirector, Livision of Planning Assistance, Office' of the Assistant Secretary for Metropolitán Development, HUD, Washington, D.C. Corresponcence of February 6, 1970 .

Thompson, Norman H., Jr., Director, Tampa Bay Regional Planning Council, St. Petersburgh, Florida. Correspondence of December 30, 1969.

Toth, Anthony K., Program Lirector, Northeast Ohio Areawide Coordinating Ágency, Cleveland, Ohio. Correspondence of January 5 , 1970 . 
Correspondence with Richard C. Hartman, Director, National Service to Kegional Councils, Washington, D.C. of Septerber 2.5, 1969.

Ullman, Al, Nember of Congress, House of Representatives, Washington, D.C. Correspondence of October 22, 1969.

Watkins, Wilbert F., Director, Falls of the Ohio Netropolitan Council of Governments, Louisville, Rentucky. Correspondence of December 30, 1969.

Weiss, Lizette, Community Relations Assistant, Association of Bay Area Governments, Berkeley, California. Lorrespondence of October 24, 1969, and September 28, 1970.

Werblow, Jack, Director of Current Planning, Ohio-KentuckyInciana, Regional Planning Authority, Cincinnati, Ohio. Correspondence of December 26, 1969.

Wingett, Mel, Acting Executive Lirector, Council of Fresno County Governments, Fresno, California, Correspondence of October 20,1969 .

\section{INTERVIEVS}

Cease, Ronald C., Associate Frofessor, Portland State University, Portland, Oregon. Several interviews over an extended period of time.

Hallock, Peter, Director, Fortland Wetropolitan Boundary Commission, Portland, Oregon. Interview of September $23,1970$.

Rich, A. McKay, Executive Director, Portland Netropolitan Study Commission, Portland, Oregon. Several interview over an extendeci period of time.

Van Asselt, Karl, Assistant Director, League of Oregon Cities, Salem, Oregon. Interviev: of September 23, 1970 . 


\section{APPENDIX A}

REGIONAL COUNCILS ${ }^{1}$

Generally, there are five different categories of regional councils: Councils of Governments, Economic Development Districts, Regional Planning Commissions, Transportation Study Groups, and other unique regional bodies. 2

Councils of Governments are associations of local governments predominently represented by their elected officials. These councils are mainly concerned with providing a regional forum for the discussion of common issues and the determining of policies and priorities on these issues. While comprehensive planning is a prime concern, council interests are oriented to any and all areawide metropolitan problems.

Economic Develoment Districts are generally nonprofit corporations which coordinate public and private efforts within a regional area to promote economic

Information for the appendix has been obtained from the National Service to Regional Councils, Regional Council Profiles, or. cit., p.iii.

2 The multi-state regional commissions created by Congress in 1965 are not classified as regional councils in the same sense as those inaicated. Each of the se commissions include several states and have only state and federal representatives on their governing bodies. 
progress and development. A district can be created only if the area in which it is located meets specified federal criteria, such as high unemployment rates or low average income levels. Most district governing bodies are composed of elected officials of local governments and of representatives from the major economic and sooial interest groups in the area.

Regional Planning Commission, however, are organizations with a major responsibility for comprehensive areawide planning, traditionally emphasizing land use planning and the coordination of local plans. Many commissions are official agencies of the states, formed by specific state acts or general enabling legislation. The governing bodies of these commissions usually are composed of citizens appointed by state and local governments. There are many regional bodies which are called regional planning commissions which are actually councils of governments. The major oifferences usually are related to the fact that commissions are usually state or state-controlled bocies.

Transportation Study Groups are organization directly responsible for the highway and mass transit planning for local governments in regional areas. Most transportation planning groups were established to comply with the Federal-Aid Highway Act of 1962. Many are not regional councils, but are local extensions of the state highway 
departments. Others have been gradually taken over by other forms of regional councils. The governing bodies are usually similar to the regional planning commissions, but their major area of emphasis is with state and transportation-oriented bocies.

Other regional councils include the unique forms established in the Minneapolis-St. Paul region of Minnesota, called simply the Metropolitan Council, and the. Hudson River Valley Commission in New York. These are essentially experimental organizations, but can be classified as regional councils because of their multi-jurisdictional nature and their emphasis on areawide planning and coordination. 


\section{APPENDIX B}

A PARTIAL LISTING OF COUNCILS OF GOVERNMENTS

Alabama:

Anniston Calhoun County Council of Governments

Florence Muscle Shoals Council of Local Governments

Tuscaloosa Tuscaloosa Area Council of Local Governments

Arizona:

Phoenix Maricopa Association of Governments

Tucson

Tucson Urban Area Regional Reviewing Committee

Arkansas :

Bentonville- Northwest Arkansas Regional Planning Fayette- Commission

vilie

California:

Bakersfield Kern Lounty Regional Planning Advisory Commission

Fresno Council of Fresno County Governments

Hanford King County Regional Flanning Agency

Los Angeles

Southern California Association of Governments

Merced

Redding

Merced County Association of Governments

Shasta County and Cities Area Planning Council

Sacramento

San Diego

Sacramento Regional Planning Commission

San Liego County Comprehensive Planning Organization

San Fran- Association of Bay Area Governments ciscoOakland

Santa Barbara Santa Barbara County-Cities Area Planning Council

Santa Cruz Santa Cruz County Regional Planning Agency

Stockton

County of San Joaquin Aòvisory Planning Association 
Colorado:

Denver Denver Regional Council of Governments

Connecticut:

Hartford Caritol Region Council of Elected Officials

District of Columbia:

Washington Metropolitan Washington Council of Governments (inclucies portions of Maryland and Virginia)

Florida:

St. Peters- Tampa Bay Area Regional Planning Counburg-Tampa cil

Georgia:

Atlanta Metropolitan Atlanta Council of Local Governments

Columbus Valley Council of Local Governments

Illinois:

Chicago Council of Governments of Cook County

Iowa:

Des Moines Mid-Iowa Association of Local Governments

Sioux City Siouxland Interstate Metropolitan Planning Council (includes portions of Nebraska)

Kentucky:

Louisville Falls of the Ohio Metropolitan Council of Governments (includes portions of Indiana)

Louisiana : Baton Rouge Capital Regional Planning Commission
New Orleans ferson, Orleans and St. Bernard Parishes

Maine:

Portland Greater Portland Council of Governments

Maryland:

Baltimore Regional Planning Council

Waldorf Tri-County Council for Southern Maryland

Massachusetts:

Boston

Metropolitan Area Planning Council 
Michigan:

Detroit

Detroit

Grand Rapids

Grand Rapids

Southeast Michigan Council of Governments

Supervisors Inter-County Committee (Disbanded in 1967)

Association of Grand Rapids Area Governments

Kent-Ottawa Regional Planning Commission

Minnesota:

Duluth-

Superior

Head of the Lakes Council of Governments

Missouri:

Kansas City Mid-American Council of Governments (includes portions of Kansas)

Popular Bluff Ozark Foothills Regional Planning Com-

St. Louismission

East St.

Louis

West Plains

East-West Gateway Coordinating Council (includes portions of Illinois)

South Central Ozark Regional Planning Council

Nebraska:

Omaha-

Council

Bluffs

Omaha-Council Bluffs Metropolitan Area Planning Agency (incluces portions of Iowa)

Nevaca:

Las Vegas

Clark County Regional Planning Commission

New Mexico:

Albuquerque Middle Rio Grande Council of Governments of New Mexico

New York:
Albany

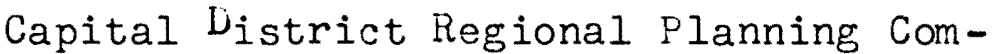 mission
New York
Metropolitan Regional Council (includes portions of Connecticut and New Jer- sey.)

North Carolina:

Greensboro- Piedmont Triad Council of Governments Winston-Salem

Shelby

Cleveland Association of Governmental officials 
North Carolina (continued):

Wilmington Lower Cape Fear Council of Local Governments

Winston-

Salem

Forsyth Council of Governments

Ohio:

Cincinnati Ohio-Kentucky-Indiana Regional Planning Authority

Cleveland Northeast Ohio Areawide Coordinating Agency

Dayton

Youngstown Mahoring-Trumbull Counties Comprehen-

Miami Valley Council of Governments sive Transportation Study Group

Oklahoma:

Oklahoma City Association of Central Oklahoma Governments

Oregon:
Albany
Linn-Benton Association of Governments
Eugene
Central lane Planning Council
Medford
Rogue Valley Council of Governments
Portland
Columbia Region Association of Govern- ments (includes portions of washing- ton)
Roseburg
Central Umpqua Regional Planning Coun- cil
Salem
Mid-Willamette Valley Council of Gov- ernments

Pennsylvania:

Philadelphia Penjerdel Council of Governments (formerly the Regional Conference of Elected Officials)(includes portions of Delaware and New Jersey)

Pittsburgh Allegheny Council for Intergovernmental Action

State College Centre Regional Council of Governments

Stroudsberg Tocks Island Regional Advisory Council.

Tennessee:

Bristol

Bristol, Tennessee-Virginia Joint Planning Commission

Chattanooga

Chattanooga Area Regional Council of Government,s

Knoxville

Memphis

Knoxville Area Council. of Governments

Nashville

Mississippi-Arkansas-Tennessee Council of Governments

Mid-Cumberland Council of Governments 
Texas:

$A B i l e n e$

Corpus Christi

Dallas-Fort Worth

El Paso

HoustonGalveston

Lubbock

Orange

San Antonio

Texarkana

Tyler

Victoria

Utah:

Salt Lake City

Washington:

Bellingham

Seattle

Wenatchee

Yakima

West Virginia:

Wheeling

Wisconsin:

AppletonOshkosh

Milwaukee
West Central Texas Council of Governments

Costal Bená Regional. Planning Commission

North Central Texas Council of Governments

El Paso Council of Governments

Houston-Galveston Area Council

Lubbock Metropolitan Council of Governments

Orange County Council of Governments

Alamo Area Council of iovernments

Ark-Tex Council of lovernments (includes portions of Arkansas)

Snith County-Tyler Area Council of Governments

Golden Crescent Council. of Governments

Salt Lake County Council of Governments

Whatcom County Regional Planning Council

Puget Sound Governmental Conference

Chelan-Douglas Regional Planning Council

Yakima County Conference of Governments

Belmont-Ohio-Marshall Counties Metropolitan Planning Committee

Fox Valley Council of Governments

Milwaukee County Intergovernmental Cooperation Council 